University of South Florida

DIGITAL COMMONS

Digital Commons @ University of

@ UNIVERSITY OF SOUTH FLORIDA

South Florida

$1-1-2009$

\title{
2009 Annual Report USF St. Petersburg
}

USF

Follow this and additional works at: https://digitalcommons.usf.edu/usf_accountability_reports

\section{Scholar Commons Citation}

USF, "2009 Annual Report USF St. Petersburg" (2009). USF Accountability Reports. 3.

https://digitalcommons.usf.edu/usf_accountability_reports/3

This Article is brought to you for free and open access by the USF Archives at Digital Commons @ University of South Florida. It has been accepted for inclusion in USF Accountability Reports by an authorized administrator of Digital Commons @ University of South Florida. For more information, please contact digitalcommons@usf.edu. 


\section{Florida Board of Governors \\ State University System (SUS) Annual Report}

\section{University of South Florida-St. Petersburg}

Approved by the USF Board of Trustees

December 16, 2009 


\section{$\underline{\text { Data Definitions }}$}

\section{GOAL 1:}

- Baccalaureate Degrees Awarded and Graduate Degrees Awarded: Graduate degrees include master's, research doctoral, and professional doctoral programs. Source: SUS Student Instruction File

\section{- \# and \% Baccalaureate Degrees Awarded (Non-Hispanic Blacks and Hispanics):} The number of baccalaureate degrees granted to non-Hispanic black students or Hispanic students. The percentage is the number of baccalaureate degrees awarded to each group divided by the total number of degrees awarded, excluding those awarded to non-resident aliens and those not reporting race/ethnicity. Source: SUS Student Instruction File

- \# and \% Baccalaureate Degrees Awarded (Pell Recipients): The number of baccalaureate degrees awarded to federal Pell grant recipients, an indicator of low family income. For this report, a Pell grant recipient is defined as a student who received Pell within six years of graduation. The percentage is the number of baccalaureate degrees awarded to Pell recipients as listed above divided by the total number of degrees awarded, excluding those awarded to non-resident aliens. Sources: SUS Student Instruction File and Student Financial Aid File

\section{GOAL 2:}

- \# Degrees Awarded in Select Areas of Strategic Emphasis: Degrees as reported above by six-digit Classification of Instruction Program. The areas of strategic emphasis were selected by the Board of Governors staff in consultation with business and industry groups.

- Pass Rates on Professional Licensure Examinations: Many professional licensure data, gathered by the respective licensing boards and housed within the Department of Business and Professional Regulation, are not currently formatted and do not contain sufficient information to match to SUS data. Board of Governors staff will work with individuals from the appropriate agencies to try to get data in the needed format.

\section{GOAL 3:}

- Federally Financed and Total Academic Research and Development Expenditures: The National Science Foundation conducts an annual survey of colleges and universities regarding research and development expenditures. These amounts combine reported science and engineering R\&D expenditures with reported nonscience and engineering expenditures. Dollars are in nominal dollars (i.e., not inflationadjusted). Source: http://webcaspar.nsf.gov/ 
- \# Licenses/Options Executed: Count of the number of licenses/options executed in the fiscal year for all technologies. Each license agreement is counted separately. Source: AUTM Licensing Survey

- Licensing Income Received: License issue fees, payments under options, annual minimums, running royalties, termination payments, amount of equity received when cashed-in, and software and biological material end-user license fees of $\$ 1,000$ or more, but not research funding, patent expense reimbursement, valuation of equity not cashed-in, software and biological material end-user license fees of less than $\$ 1,000$, or trademark licensing royalties from university insignia. Source: AUTM Licensing Survey

\section{$\underline{\text { RESOURCES, EFFICIENCIES, AND EFFECTIVENESS }}$}

\section{- 6 -Year Graduation and Retention Rates (FTICs), 4-Year Graduation and Retention Rates (AA Transfers), 5-Year Graduation and Retention Rates (Other Transfers): An} FTIC cohort is defined as undergraduates entering in fall term or summer continuing to fall with fewer than 12 hours earned since high school graduation. An AA Transfer cohort is defined as undergraduates entering in fall term or summer continuing to fall and having earned an AA degree from an institution in the Florida College System. An Other Transfer cohort is defined as undergraduates entering in fall term or summer continuing to fall who are not FTICs or AA transfers. The rate is the percentage of the initial cohort that had either graduated from or was still enrolled in the sixth academic year for FTIC students, fourth year for AA Transfers, and fifth year for Other Transfers. Both full-time and part-time students are included in the calculation. Source: SUS Retention File

- Student-Faculty Ratio: The ratio of full-time equivalent students (full-time plus 1/3 part time) to full-time equivalent instructional faculty (full time plus $1 / 3$ part time). In the ratio calculations, exclude both faculty and students in stand-alone graduate or professional programs such as medicine, law, veterinary, dentistry, social work, business, or public health in which faculty teach virtually only graduate-level students. This metric does not count undergraduate or graduate student teaching assistants as faculty. Source: Common Data Set/IPEDS

- Funding per FTE Student: E\&G appropriation and tuition revenues are divided by total student FTE. Only state-fundable credit hours are used. To allow for national comparisons, FTE for this metric uses the standard IPEDS definition of FTE, equal to 30 credit hours for undergraduates and 24 for graduates. Sources: Operating Budget, SUS Student Instruction File 


\begin{tabular}{|c|c|c|c|c|c|c|c|}
\hline \multicolumn{8}{|c|}{ The University of South Florida - St. Petersburg Campus 2009 Annual Report } \\
\hline \multicolumn{3}{|c|}{ Sites and Campuses } & & & & & \\
\hline Enrollments & $\#$ & $\%$ & \multicolumn{3}{|c|}{ Degree Programs Offered (2007-08) } & \multicolumn{2}{|r|}{ Carnegie Classification } \\
\hline $\begin{array}{c}\text { TOTAL } \\
\text { (Fall 2008) }\end{array}$ & 3,771 & -- & \multicolumn{2}{|l|}{ TOTAL } & 32 & $\begin{array}{c}\text { Undergraduate } \\
\text { Instructional Program: }\end{array}$ & \multirow{10}{*}{$\begin{array}{l}\text { Carnegie Classification not available for } \\
\text { campuses at this time. }\end{array}$} \\
\hline Black & 282 & $7 \%$ & \multicolumn{2}{|c|}{ Baccalaureate } & 23 & Graduate Instructional & \\
\hline Hispanic & 289 & $8 \%$ & \multicolumn{2}{|c|}{ Master's \& Specialist's } & 9 & Program: & \\
\hline White & 2,968 & $79 \%$ & \multicolumn{2}{|c|}{ Research Doctorates } & 0 & Enrollment Profile: & \\
\hline Other & 232 & $6 \%$ & \multicolumn{2}{|c|}{ Professional Doctorates } & 0 & Undergraduate Profile: & \\
\hline Full-Time & 2,027 & $54 \%$ & \multirow{2}{*}{ Faculty (Fall 2008) } & \multirow{2}{*}{$\begin{array}{l}\text { Full- } \\
\text { Time }\end{array}$} & \multirow{2}{*}{ Part-Time } & Size and Setting: & \\
\hline Part-Time & 1,744 & $46 \%$ & & & & \multirow{2}{*}{ Basic: } & \\
\hline Undergraduate & 3,136 & $83 \%$ & TOTAL & 113 & 9 & & \\
\hline Graduate & 447 & $12 \%$ & Tenure/T. Track & 87 & 1 & \multirow{2}{*}{ Elective Classification: } & \\
\hline Unclassified & 188 & $5 \%$ & Non-Ten. Track & 26 & 8 & & \\
\hline
\end{tabular}

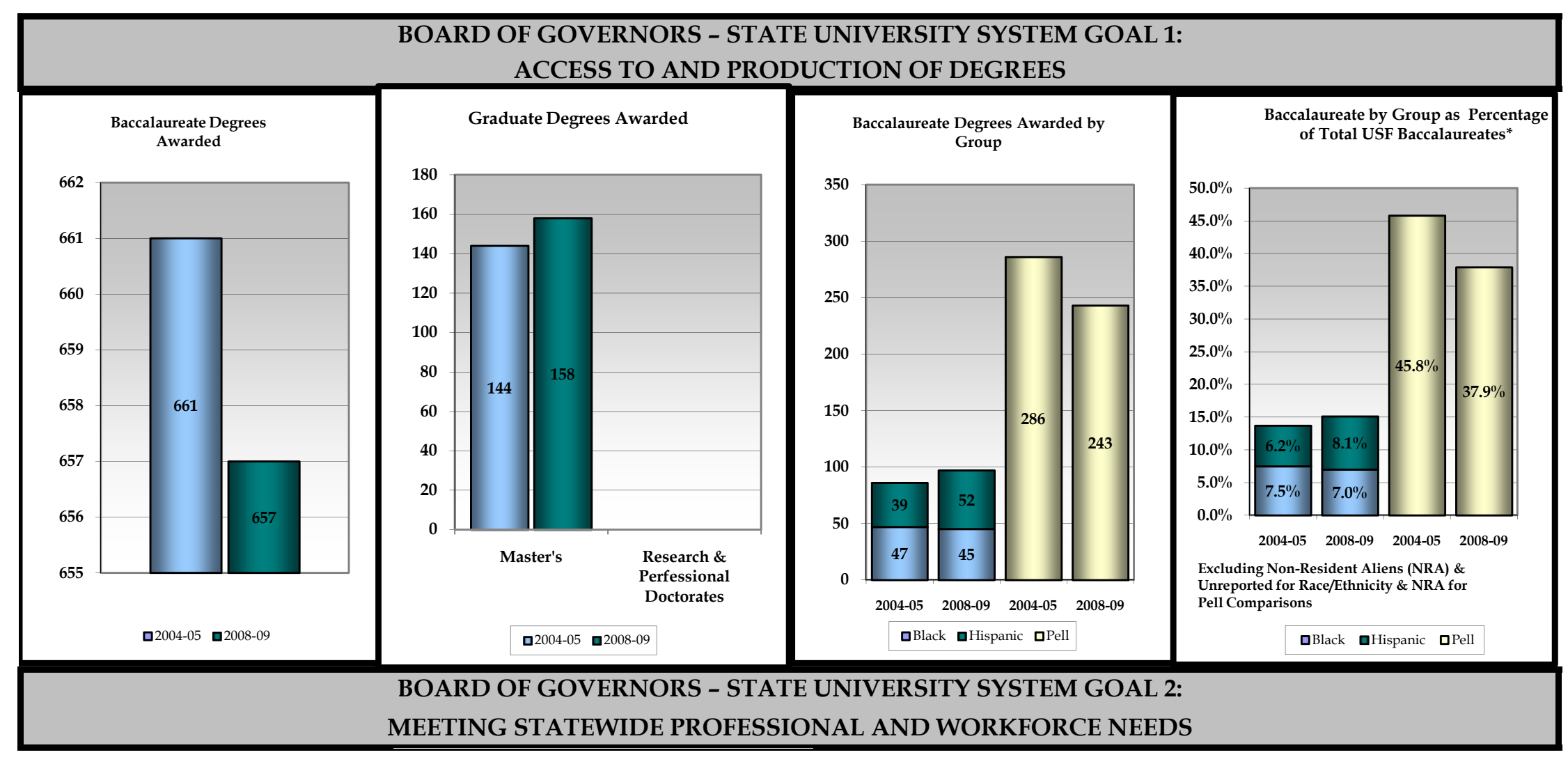



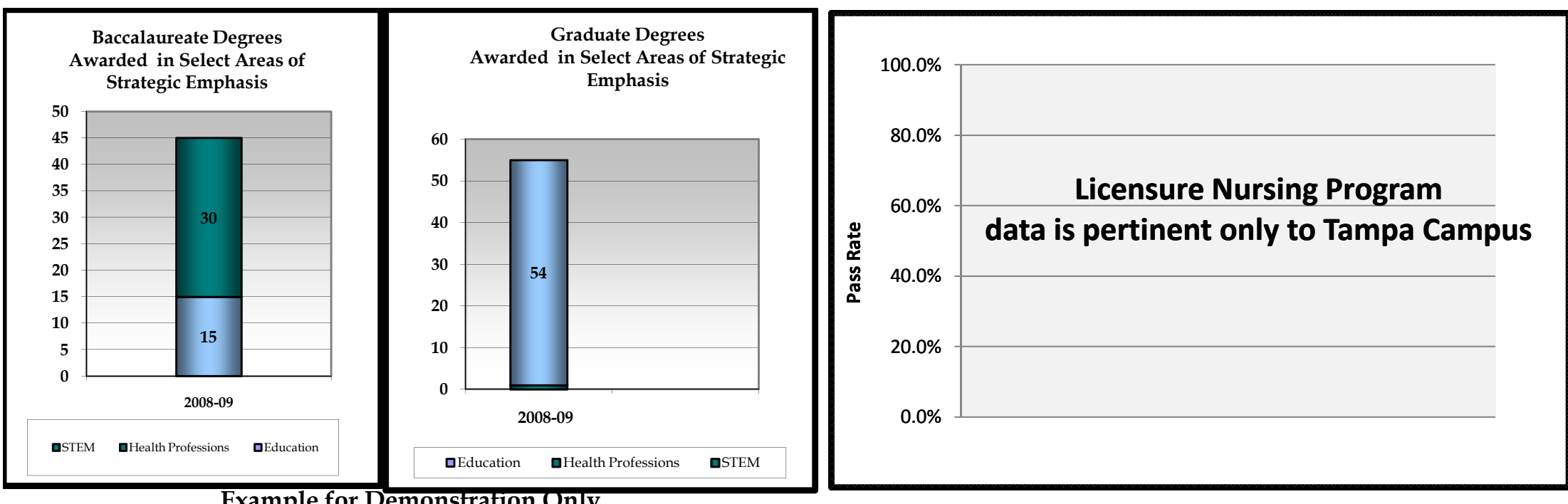

Example for Demonstration Only.

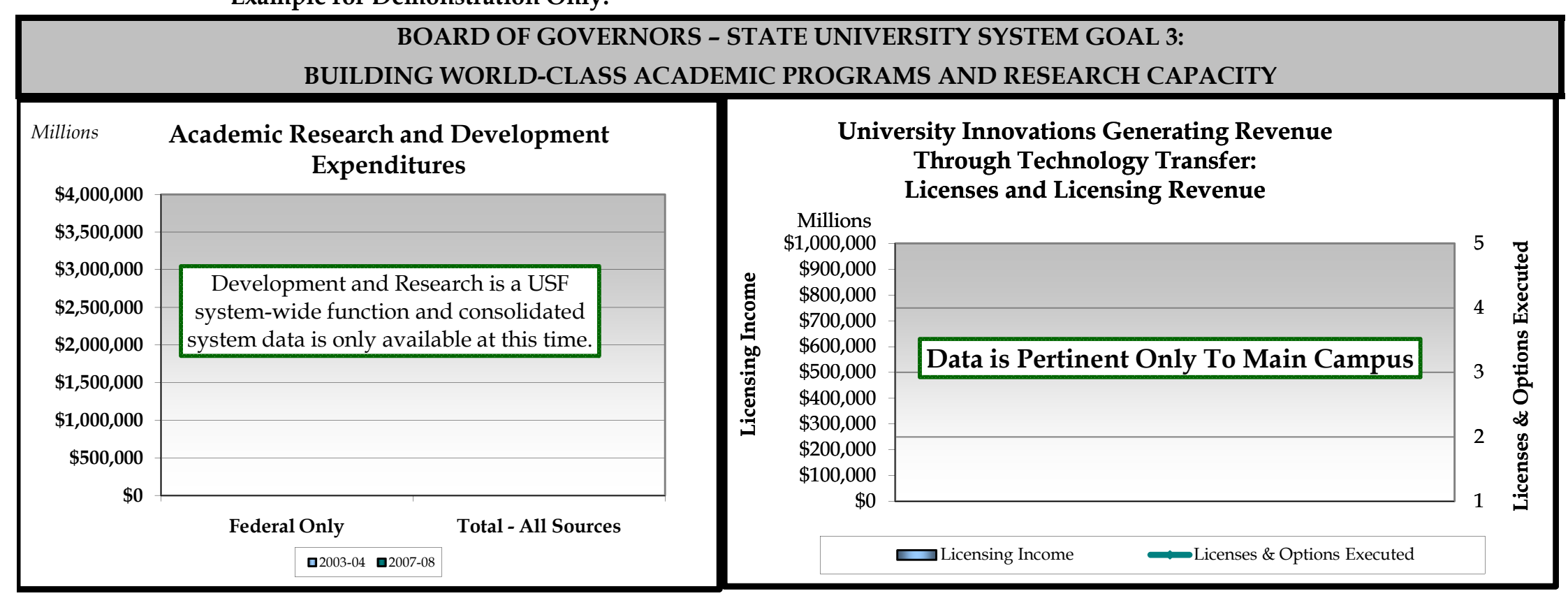



Aspen Institute's "Beyond Gray Pinstripes" which is based on the strength of an institution's programs in corporate and social responsibility.

The USFSP Debate team was established in 2008 and placed 8th out of 48 teams in its first competition and it continues it winning ways.

The USFSP Chapter of Beta Alpha Psi (accounting) Honor Society received the designation of "superior" from the national organization.

Gerald Lander, the Gregory, Sharer \& Stuart P.A., Professor in Forensic

Accounting, was named the 2008-2009 Outstanding Accounting Educator in Florida by the FICPA. Dr. Lander was recognized at a meeting of the Board of Governors in Tallahassee.
- The College of Education underwent its first site visit for continuing program approval by the Florida Department of Education in 2008 and received "Full Approval" for its MA in Elementary Education/ESOL. The program's reading competency matrix was deemed a model for the state by the Office of Just Read! Florida.

Lyman Dukes launched Project 10: Transition Education Network, a \$1.02 million dollar annual project funded by the Florida Department of Education to increase access to higher education for persons with disabilities throughout Florida.

\section{- Institutional awards/achievements}

Completed construction and began operations in the Science and Technology Building.

Completed the Harborwalk at USFSP (a new campus entrance).

BOARD OF GOVERNORS - STATE UNIVERSITY SYSTEM GOAL 4: MEETING COMMUNITY NEEDS AND FULFILLING UNIQUE INSTITUTIONAL RESPONSIBILITIES

[AVAILABLE FOR DISPLAY OF INSTITUTIONAL PERFORMANCE ON MEASURES RELATED TO MEETING COMMUNITY NEEDS AND FULFILLING UNIQUE INSTITUTIONAL RESPONSIBILITIES] 


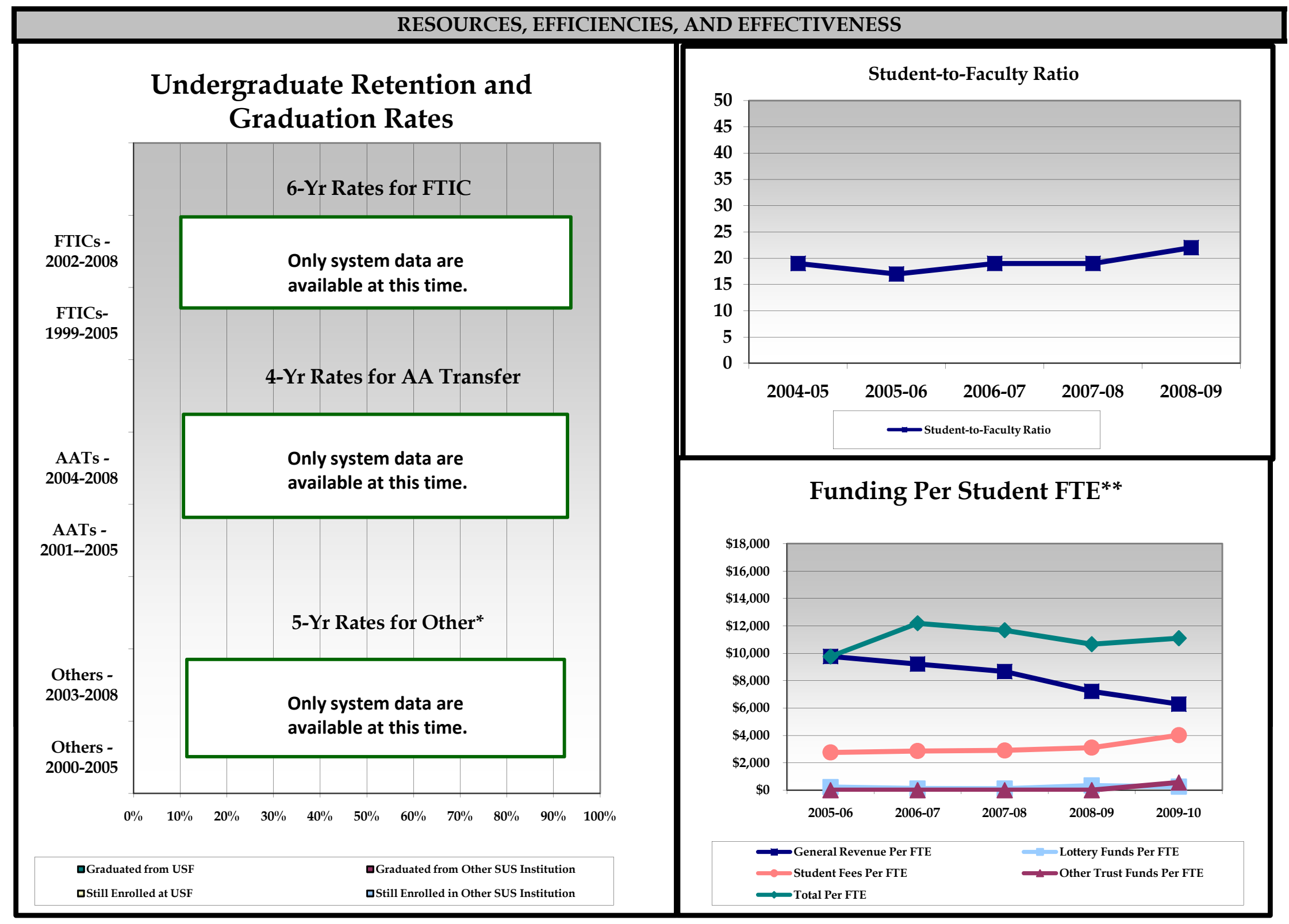

* The composition of "Other Transfer" cohorts may vary greatly by institution.

** FTE for this metric uses the standard IPEDS definition of FTE, equal to 30 credit hours for undergraduates and $\mathbf{2 4}$ for graduates. 


\section{$\underline{\text { Introduction }}$}

\section{- Mission}

The University of South Florida St. Petersburg offers distinctive graduate and undergraduate programs in the arts and sciences, business, and education within a close knit, student-centered learning community that welcomes individuals from the region, state, nation, and world. We conduct wide-ranging, collaborative research to meet society's needs and engage in service projects and partnerships to enhance the university and community's social, economic and intellectual life. As an integral and complementary part of a multiinstitutional system, USF St. Petersburg retains a separate identity and mission while contributing to and benefiting from the associations, cooperation, and shared resources of a premier national research university.

http://www.stpete.usf.edu/strategicplanning

\section{- Vision}

The University of South Florida St. Petersburg will be a premier master's urban university recognized for its vibrant community of scholars who engage and improve its community and the world. http://www.stpete.usf.edu/strategicplanning

\section{- Other Contextual Introductory Comments}

The University of South Florida St. Petersburg (USFSP) was first accredited as a separate institution in 2006. It is now and will continue to be a member of the University of South Florida system of institutions which include USF Tampa, USF Sarasota/Manatee (now seeking separate accreditation) and USF Polytechnic (will seek separate accreditation in 2010). Over the past three years, USFSP has strengthened both its academic and its research profile. The opening of a residence hall for students in fall 2006 represented a milestone in the realization of the institution's Strategic Plan. Since 2006 there has been a rapid growth in FTIC enrollment and a concomitant rapid increase in student organizations, on-campus student life activities, and student support services. USFSP is on a path to realize its vision as a Masters comprehensive university serving regional needs yet reaching nationally and globally in support of the USF system goals.

\section{BOARD OF GOVERNORS - STATE UNIVERSITY SYSTEM} GOAL 1: ACCESS TO AND PRODUCTION OF DEGREES

USF St. Petersburg's enrollments have been steadily growing over the past three years, from a total of 3,371 home campus/5,003 funding campus (headcount) students in Fall 2006 to 3,771 home campus/5640 funding campus (headcount) students in Fall 2008. The suite of degree program offerings, both at the undergraduate and graduate level have been selected and refined to reflect regional needs and to complement those at other USF system member institutions. USFSP offers a robust academic environment for transfer students although the growth of the state college system has been a challenge to recruitment for this group of students.

Overall degree production has remained steady from 06-07 to 08-09 with 635 baccalaureate degrees awarded in AY2006-2007 and 653 awarded in AY 2008-2009; and 143 graduate degrees awarded in AY2008-09 and 152 graduate degrees awarded in AY2008-09.

The demographic profile of USFSP students reflects the population of the region. USFSP's academic environment benefits students from all demographic groups due to its relatively small classes and the commitment of faculty and staff to student success and to providing students with outstanding service in all areas. 


\section{BOARD OF GOVERNORS - STATE UNIVERSITY SYSTEM GOAL 2: MEETING STATEWIDE PROFESSIONAL AND WORKFORCE NEEDS}

USF St. Petersburg is focused on meeting both regional and statewide professional and workforce needs. It accomplishes this goal by offering degree programs that address high-need areas within Florida's workforce. For example, the College of Education revised and refined its undergraduate degree offerings specifically in response to the need of local school districts for elementary school teachers who are qualified to teach every child, including children with exceptional needs and children whose first language is not English. The new B.S. degree (initiated in 2009) will enable graduates to be highly flexible in their employment. It will also give principals and superintendents high confidence that USFSP graduates are wellequipped for success in many educational settings.

The Graphic Design program, approved by the BOG as a limited access program, instills in graduates both the intellectual foundations and the practical skills for success in "new media" as the media and graphic design industries around the region, the state and the nation move further, and often exclusively, into the electronic realm. USFSP graduates are in demand since this program is highly competitive and only a small number of exceptional students proceed to completion. The program has strong synergy with the Journalism and Media Studies degree programs (both baccalaureate and masters) and a number of courses allow students from both programs to enroll.

The College of Business offers a unique milieu in which business education is placed. The College has a special focus on corporate and social responsibility, that is, the ethical and responsible conduct of business. The College has been consistently ranked in the top 50 institutions in the nation for its achievements in this area. USFSP graduates in both business and accounting are sought after by Florida firms since this ethos or corporate and social responsibility is highly valued and few institutions make it a focus of their programs.
BOARD OF GOVERNORS - STATE UNIVERSITY SYSTEM GOAL 3: BUILDING WORLD-CLASS ACADEMIC PROGRAMS AND RESEARCH CAPACITY

USFSP has built and is building outstanding academic programs and is expanding research capacity in keeping with its mission.

For example:

- The College of Business received accreditation in both business and accounting programs from AACSB International. AACSB International accreditation has been awarded to only 570 institutions which represent less than 10 percent of eligible institutions worldwide. Of these, only 171 institutions have achieved accreditation in both business and accounting.

- The College of Business was ranked \#36 in the world in the Global 100 ranking of the Aspen Institute's "Beyond Gray Pinstripes" which is based on the strength of an institution's programs in corporate and social responsibility.

- The College of Education was approved for candidacy by the National Council of Teacher Accreditation (NCATE) in 2006.

- The College of Education underwent its first site visit for continuing program approval by the Florida Department of Education in 2008 and received "Full Approval" for its MA in Elementary Education/ESOL. The program's reading competency matrix was deemed a model for the state by the Office of Just Read! Florida.

- The College of Education received "Full Approval" by the Florida Department of Education in 2008 for all programs leading to state licensure.

- The Department of Journalism and Media Studies (College of Arts and Sciences) achieved accreditation through the Accrediting Council on Education in Journalism and Mass Communication in 2003, one of only 114 such accredited programs in the US.

- The institution developed a distinctive undergraduate minor in leadership studies that encompasses both curricular and cocurricular elements and now includes a residential learning community and which has been noted by leading national scholars of leadership as "teaching the new leadership in the new way." 


\section{BOARD OF GOVERNORS - STATE UNIVERSITY SYSTEM GOAL 3: BUILDING WORLD-CLASS ACADEMIC PROGRAMS AND RESEARCH CAPACITY (Continued)}

- The College of Education developed a new, unique undergraduate degree, the B.S. in Education that provides the successful student with licensure in elementary education and exceptional student education as well as state-approved endorsements in reading and ESOL.

- USFSP has greatly expanded and strengthened its focus on undergraduate research with faculty. Undergraduate research has been shown to be a key element in placing students in premier graduate programs and it has also been shown to improve both student academic performance and persistence.

- Many USFSP faculty are recognized around the nation and the world as leading scholars in their fields. For example:

- Dr. Ray Arsenault has been recognized for his work on the civil rights movement.

- Dr. Gary Mormino is a leading scholar on modern Florida history

- Dr. Sheramy Bundrick has been able to move seamlessly between her work as an art historian and creative writing of historical fiction.

- Dr. Lyman Dukes is the national authority on standard for access to higher education and school-to-work transitions for person with disabilities.

- Dr. Malcolm Butler is a nationally-recognized scholar in science education and science teacher education, particularly his work with the National Science Foundation to increase African Americans in the field.

- Dr. Mark Durand is a highly regarded scholar in the field of autism and a prolific textbook author

- Dr. John Arthur is a nationally-known scholar in anthropology with support from the National Science Foundation for his work in Ethiopia

- Dr. Jamie McHale, Professor of Psychology and founder of the USFSP Family Studies Center engages in multiple research projects funded by the National Institute of Child
Health and Development (NICHD). One project, aligned with the Hillsborough County Sheriff Department and the USF Florida Kinship Center, is designed to promote healthy co-parenting skills among incarcerated mothers and other caregivers. In a second project the FSC currently partners with both Pinellas County Health Department and Mt. Zion Human Services Center to perform prenatal interventions with first-time African-American mothers to promote better post-natal co-parenting. 


\section{BOARD OF GOVERNORS - STATE UNIVERSITY SYSTEM GOAL 4: MEETING COMMUNITY NEEDS AND FULFILLING UNIQUE INSTITUTIONAL RESPONSIBILITIES}

The University of South Florida St. Petersburg reflects its commitment to meeting community needs and fulfilling unique institutional responsibilities in its mission statement and strategic goals.

- As an example of this commitment in action, USFSP's Center for Civic Engagement (CCE) was founded in 2006. The CCE has catalyzed and funded curricular innovations that focus on civic scholarship and has itself been responsible for contributing nearly 238,000 hours to local and regional community organizations with an estimated value of more than $\$ 4.5$ million since its founding.

- In June of 2009, the College of Education, SRI International, and the Pinellas County Schools began a unique collaborative designed to give the Pinellas schools the capacity to integrate a digital math curriculum and teacher professional development into a coherent and effective approach to algebra and geometry instruction. "Given our strong partnership with the district, the opportunity to combine SRI's innovative digital math curriculum and the college's expertise in math education created the ideal combination for achieving our shared goal of sustainable change," Dean Vivian Fueyo, College of Education. (See the press release for more information) http://www.stpt.usf.edu/coe/documents/SunbayDigitalMath.pdf

- College of Education faculty continue to produce nationally and internationally recognized research and scholarship in science education, math education, English for Speakers of Other Languages (ESOL), and educating persons with disabilities. Highlights of USFSP College of Education faculty accomplishments in 2009 include: 1) in science education, Dr. Malcolm Butler, served as the sole science educator on a four- member team that produced National Geographic's first science literacy curriculum; 2) in math education, Dr. Andy Reeves published Cartoon Corner: Mathematics Teaching in the Middle School for the National Council for Teachers of Mathematics; 3) in ESOL, Dr. Alejandro Brice, published Language Development: Monolingual and Bilingual Acquisition for Allyn \& Bacon, a major national publisher; and in special education, Dr. Lyman Dukes launched Project 10: Transition Education Network, a \$1.02 million dollar annual project funded by the Florida Department of
Education to increase access to higher education for persons with disabilities throughout Florida.

- Dr. Trey Conner, Assistant Professor of Writing, collaborated with Mt. Zion Human Services, a local non-profit organization, to create new uses for old computers. The Center, which serves residents in an area challenged by poverty and crime in Pinellas County, had a fleet of computers that could no longer run mainstream software. Faced with few options and no budget, this project provided Mt. Zion afterschool programs with much needed education computing infrastructure essentially for free using open source software. Open source technology has a much lower cost because it bears no licensing fees for programs. The technology network moves away from the personal desktop computer model and relies upon central servers with client machines.

- Dr. John Arthur, Associate Professor of Anthropology, received permission from the Weedon Island Cultural and Natural History Center, Progress Energy, and the State of Florida Historical Preservation Office, to start the first systematic excavation of artifacts at Weedon Island. Dr. Arthur and his students from USFSP have begun to research and document cultural and environmental changes of this land, once inhabited by Native Americans.

- Dr. Michiko Otsuki, Assistant Professor of Psychology, worked with the Suncoast Pediatric Asthma Coalition, to co-sponsor "Asthma Family Day" at USFSP. This interactive event is designed to improve asthma self-management skills and awareness for children with asthma and their families and strengthen the partnership between the medical community, families and schools working with children who have asthma.

- The College of Education and the College of Arts and Sciences at USFSP have joined forces to increase the number of qualified middle and high school teachers. Approved by the Florida Department of Education, this joint Professional Training Option (PTO) offers liberal arts students from selected majors the opportunity to supplement their curriculum with 12 credit hours from the College of Education and a teaching practicum within the Pinellas County School District. The program prepares students for the Florida Teacher Certification exam. 


\section{Additional Information on Quality, Resources, Efficiencies, and}

\section{Effectiveness}

The University of South Florida St. Petersburg has been challenged as never before by the statewide budget and economic crisis. This challenge has resulted in actions to re-engineer many of its processes and reorganize its administrative functions to increase efficiency and deliver outstanding student services with reduced resources. For example, Academic Affairs and Student Affairs realigned admissions, financial aid, registration and records, and student academic support (tutoring center) functions to enable better service to more students with fewer people.

In addition, over the past three years, the institution has also continued to respond to the concerns of the Southern Association of Colleges and Schools. Earlier in 2009, the institution successfully cleared all outstanding issues and is now proceeding on the usual and customary path to reaffirmation of accreditation. The institution was also successful in achieving separate accreditation for both its business and accounting programs from the Association to Advance Collegiate Schools of Business International (AACSB International), a designation achieved by only 10 percent of business schools worldwide. In addition, the institution underwent a successful visit and review by the Florida Department of Education for all programs leading to state licensure and had a successful visit by a team from the National Council for the Accreditation of Teacher Education (NCATE) which we are confident will result in full accreditation in Spring 2010.

\section{Additional Resources}

[For example, university links should be included for the following]

\section{- University Institutional Research Unit} www.stpete.usf.edu/ir

\section{Section 9 of Annual Report: Progress on Other Primary Institutional Goals and Metrics as Outlined in the University Work Plan}

The University of South Florida St. Petersburg's Strategic Plan for 2009-2013 includes six over-arching goals, each of which includes subgoals. Each sub-goal includes 1-, 3- and 5-year strategic objectives which have been structured to recognize budget realities while still advancing the overall mission of the institution. At this time, work groups have been established to address Year-1 strategic objectives in all six goals areas of the mission. Goals, sub-goals and strategic objectives are detailed below.

1 - Academic Performance: Support and enhance programs that prepare students to be knowledgeable, reflective and engaged citizen scholars

1.1 Use sustained evidence of student learning outcomes and student achievement for continuous improvement

Refine and continue the integrated academic assessment plan [Year 1]

Evaluate the student learning assessment tracking tools that are in place for monitoring institutional effectiveness [Year 3]

Evaluate the integrated assessment plan for efficacy and continue to refine curricula [Year 5]

1.2 Offer certificate, undergraduate, and graduate programs that meet regional needs

Develop a needs assessment based on student and community needs [Year 1]

Utilize data to review and refine existing undergraduate and graduate curricula and initiate new programs [Year 3] 


\section{Section 9 of Annual Report: Progress on Other Primary Institutional Goals and Metrics as Outlined in the University Work Plan (continued)}

Evaluate new configuration of curricula and programs [Year 5] 1.3 Implement and support information and instructional technologies that facilitate effective pedagogies

Develop policies and a plan for appropriate delivery and ownership of instruction; and create a campus-wide information and data literacy plan [Year 1]

Continue to provide faculty with the knowledge, training, and skills needed to enhance and develop appropriate instructional delivery and document continuous improvement in quality [Year 3]

Engage in monitoring appropriate deliveries and assess the information and data literacy plan and document how the process will be improved [Year 5]

1.4 Enhance programs that specifically support academic excellence.

Develop an integrated plan for academic excellence, that can involve all students, including the Honors Program, expanded opportunities for undergraduate research and workshops on academic excellence [Year 1] 3]

Expand faculty participation in academic program activities [Year

Expand student participation in academic program activities [Year 5]

1.5 Increase student awareness of participating in a global society

Identify existing curricular and programmatic content with global perspectives [Year 1]

Assess viability of central support of study abroad programs [Year 3]

Support study abroad programs [Year 5]
2 - Student Engagement: Enhance learning and achievement and promote retention through active engagement in curricular and cocurricular programs

2.1 Create a freshman experience that enables students to thrive and move successfully through to graduation

Develop an implementation plan for appropriate first year program curricula based on a review of best practices, benchmark criteria, and outcome data from other institutions [Year 1]

Implement the First Year Experience program [Year 3]

Evaluate the efficacy of the First Year Experience program and make enhancement modifications based on assessment data [Year 5]

2.2 Foster institutional pride and strengthen connections within the campus community

Promote and celebrate USFSP's identity, history, and tradition and strengthen the student experience (e.g. assess feasibility of Greek Life, design a new student center, and augment wellness and recreational activities) [Year 1]

Seek funding for a student center and conduct a feasibility study for the expansion of recreation and wellness facilities [Year 3]

Seek funding for renovation of the CAC and seek funding for expansion of recreation and wellness facilities [Year 5]

2.3 Enhance opportunities for increased student involvement in curricular and co-curricular activities

Continue to develop a student leadership development program that combines curricular and co-curricular elements and integrates ethics, leadership, and civic engagement across the curriculum [Year 1]

Implement an academic certificate program in Ethics, Leadership and Civic Engagement [Year 3]

Organize fundraising activities in support of leadership and civic engagement scholarships and programs [Year 5] 


\section{Section 9 of Annual Report: Progress on Other Primary Institutional Goals and Metrics as Outlined in the University Work Plan (continued)}

3 - Diversity and Inclusion: Create a vibrant, inviting, and enriching university community that values and respects all individuals and whose students, faculty, and staff represent the diversity of its region

3.1 Ensure an inclusive community where differences are respected and valued

Promote the Regional Chancellor's Advisory Board for Inclusion and Diversity [Year 1]

Administer a campus climate survey and report and disseminate findings [Year 3]

Evaluate the effectiveness of diversity and inclusion initiatives and make enhancement modifications based on assessment data [Year 5]

3.2 Attract and retain a diverse student population

Charge a strategic enrollment committee with developing an action plan for attracting and retaining students from diverse backgrounds [Year 1]

Implement action plan as a university-wide initiative [Year 3]

Evaluate the impact of academic courses and co-curricular programming that emphasize diversity and inclusion [Year 5] 3.3 Increase the diversity of faculty and staff

Study the processes for recruitment and retention of diverse faculty and staff [Year 1]

Develop and implement an action plan for recruitment and retention of diverse faculty and staff [Year 3]

Evaluate the recruitment and retention initiative and make enhancement modifications based on assessment data [Year 5]
4 - Research and Creative Activities: Encourage faculty research and creative activities, and engage students in local, national and international scholarship

4.1 Create a vibrant culture of faculty research and creative scholarship

Explore cost-effective ideas to support and promote faculty research and study the feasibility of establishing a local human subjects review (IRB) process. [Year 1]

Develop an action plan as a university-wide initiative that increases the number of proposals submitted and increases research funding [Year 3]

Implement the action plan and evaluate the feasibility of establishing a Faculty Research Center [Year 5]

4.2 Promote and support undergraduate research as a meaningful aspect of campus life

Open new Science and Technology Building laboratories and establish a formal process for engaging undergraduate students in research [Year 1]

Expand opportunities for undergraduate students to participate in research [Year 3]

Continue to assess undergraduate activity in research; revise the program as appropriate [Year 5]

4.3 Enhance and support research and scholarly collaborations with community partners

Identify research partners in government, health, environment, education and other nonprofit organizations [Year 1]

Establish research forums with partners in government, health, environment, education and other non-profit organizations

[Year 3]

Assess the productivity of faculty/community research and scholarly collaborations [Year 5] 


\section{Section 9 of Annual Report: Progress on Other Primary Institutional Goals and Metrics as Outlined in the University Work Plan (continued)}

5 - Environmental Stewardship: Foster stewardship of the environment and embody the values of sustainability

5.1 Enhance sustainability through energy conservation and recycling Support student organizations in environmental awareness in reducing, reusing, and recycling [Year 1]

Continue the development of energy saving initiatives and the greening of facilities on campus [Year 3]

Continue evaluation and modification of energy green plan [Year 5]

5.2 Create a community that champions environmental awareness and sustainable living

Engage students, student organizations and residence halls in environmental awareness [Year 1]

Facilitate community partnerships focused on environmental concerns [Year 3]

Support interdisciplinary research that focuses on environmental concerns [Year 5]

6 - Administrative and Financial Stewardship: Enhance revenue and provide effective and efficient financial management and ensure institutional sustainability

6.1 Create and obtain funding streams to support short and long term initiatives

Participate in the system-wide study for central services costs; and develop budget plans that maximize resources to ensure the delivery of quality education to our students [Year 1]

Implement realign budget expenditures to be reflective of the current economic status and our strategic planning goals while ensuing delivery of quality education to our students [Year 3]
Evaluate and realign budgeted expenditures to ensure the delivery of quality education to our students and alignment with strategic planning goals [Year 5]

6.2 Increase private and corporate funding

Raise private funds to support property acquisition and construction for academic instruction, student life activities, community outreach and support for professorships, chairs, scholarships and fellowships [Year 1]

Sustain the amount of private funds to support property acquisition and construction for academic instruction, student life activities, community outreach and support for professorships, chairs, scholarships and fellowships [Year 3]

Increase the amount of private funds to support property acquisition and construction for academic instruction, student life ctivities, community outreach and support for professorships, chairs, scholarships and fellowships [Year 5]

6.3 Strengthen academic infrastructure of the university to ensure the proper alignment of instruction, services, and student life

Coordinate academic unit and funding plans and establish a strategic enrollment team [Year 1]

Assess and realign resources with established institutional expectations and institutional benchmark data [Year 3]

Update academic unit plans and funding plans [Year 5] 6.4 Strengthen institutional infrastructure for the recruitment and retention of faculty and staff

Conduct a benchmark study and evaluate existing programs and professional development opportunities for faculty and staff [Year 1]

Develop an action plan for recruitment and retention of faculty and staff [Year 3]

Evaluate the recruitment and retention initiative and make enhancement modifications based on assessment data [Year 5] 6.5 Evaluate and improve facilities and processes that foster services to faculty, students, staff, and the community

Assess satisfaction with services and facilities [Year 1]

Develop a Quality Improvement plan for facilities and processes [Year 3]

Evaluate the Quality Improvement plan and make enhancement modifications based on assessment data [Year 5] 


\section{Appendices}

\section{List of Tables}

1 - Budget

2 - Federal Stimulus Dollars (ARRA)

3 - Other Core Resources

4 - Enrollment and Funding

5 - Undergraduate Education Data

A. Baccalaureate Degree Programs Implemented or Terminated

B. First-Year Persistence Rates

C. Undergraduate Progression and Graduation Rates

D. Baccalaureate Degrees Awarded

E. Baccalaureate Degrees Awarded in Areas of Strategic Emphasis

F. Baccalaureate Degrees Awarded to Underrepresented Groups

G. Baccalaureate Completions Without Excess Credit Hours

H. Undergraduate Course Offerings

I. Faculty Teaching Undergraduates

J. Undergraduate Instructional Faculty Compensation

K. Student-Faculty Ratios

L. Licensure Examination Pass Rates (Undergraduate)

M. Tuition Differential

6 - Graduate Education Data

A. Graduate Degree Programs Implemented or Terminated

B. Graduate Degrees Awarded

C. Graduate Degrees Awarded in Areas of Strategic Emphasis

D. Licensure Examination Pass Rates (Graduate)

7 - Research and Economic Development Data

A. Research and Development Expenditures

B. Other Research and Economic Development Outcomes

C. Centers of Excellence

D. Commercialization Assistance Grants

8 - Voluntary Support of Higher Education

9 - Progress on Other Primary Institutional Goals and Metrics As Outlined in the University Work Plan 


\begin{tabular}{|c|c|c|c|c|c|}
\hline \multicolumn{6}{|c|}{1 - Budget (Non-Medical) } \\
\hline & 2005-06 Actual & 2006-07 Actual & 2007-08 Actual & 2008-09 Actual & $\begin{array}{c}2009-10 \\
\text { Estimates }\end{array}$ \\
\hline \multicolumn{6}{|l|}{ Education and General } \\
\hline \multicolumn{6}{|l|}{ EEG Revenues } \\
\hline $\begin{array}{c}\text { State Funds (Recurring GR } \\
\text { \& Lottery) }\end{array}$ & $\$ 28,156,543$ & $\$ 28,243,738$ & $\$ 27,700,768$ & $\$ 25,774,396$ & $\$ 22,521,288$ \\
\hline $\begin{array}{c}\text { State Funds (Non- } \\
\text { Recurring GR \& Lottery) }\end{array}$ & $\$ 0$ & $\$ 0$ & $\$ 675,721$ & $\$ 279,190$ & $\$ 162,435$ \\
\hline $\begin{array}{c}\text { Tuition (Resident/Non- } \\
\text { Resident) }\end{array}$ & $\$ 7,530,246$ & $\$ 8,370,447$ & $\$ 9,367,715$ & $\$ 10,665,205$ & $\$ 13,525,734$ \\
\hline Tuition Differential (UG) & $\$ 0$ & $\$ 0$ & $\$ 0$ & $\$ 0$ & $\$ 401,304$ \\
\hline $\begin{array}{l}\text { Other (Include Revenues } \\
\text { from Misc. Fees \& Fines) }\end{array}$ & $\$ 226,692$ & $\$ 287,117$ & $\$ 11,317$ & $\$ 12,584$ & $\$ 19,365$ \\
\hline $\begin{array}{c}\text { Phosphate Research Trust } \\
\text { Fund }\end{array}$ & $\$ 0$ & $\$ 0$ & $\$ 0$ & $\$ 0$ & $\$ 0$ \\
\hline Federal Stimulus Funds & $\$ 0$ & $\$ 0$ & $\$ 0$ & $\$ 0$ & $\$ 1,925,121$ \\
\hline \multirow[t]{2}{*}{ TOTAL } & $\$ 35,913,481$ & $\$ 36,901,302$ & $\$ 37,755,521$ & $\$ 36,731,375$ & $\$ 38,555,247$ \\
\hline & 2005-06 Actual & 2006-07 Actual & 2007-08 Actual & 2008-09 Actual & $\begin{array}{c}2009-10 \\
\text { Estimates }\end{array}$ \\
\hline \multicolumn{6}{|l|}{ EEG Expenditures } \\
\hline Instruction/Research & $\$ 22,011,466$ & $\$ 22,789,808$ & $\$ 22,701,438$ & $\$ 20,321,741$ & $\$ 28,080,935$ \\
\hline $\begin{array}{c}\text { Institutes and Research } \\
\text { Centers } \\
\end{array}$ & $\$ 0$ & $\$ 0$ & $\$ 0$ & $\$ 0$ & $\$ 0$ \\
\hline PO\&M & $\$ 4,491,521$ & $\$ 4,181,799$ & $\$ 3,879,638$ & $\$ 3,259,211$ & $\$ 4,326,508$ \\
\hline $\begin{array}{l}\text { Administration and } \\
\text { Support Services }\end{array}$ & $\$ 3,096,265$ & $\$ 3,210,955$ & $\$ 3,213,225$ & $\$ 3,242,984$ & $\$ 3,033,350$ \\
\hline Radio/TV & $\$ 0$ & $\$ 0$ & $\$ 0$ & $\$ 0$ & $\$ 0$ \\
\hline Library/Audio Visual & $\$ 1,376,413$ & $\$ 1,651,300$ & $\$ 1,372,585$ & $\$ 1,233,804$ & $\$ 1,613,187$ \\
\hline Museums and Galleries & $\$ 0$ & $\$ 0$ & $\$ 0$ & $\$ 0$ & $\$ 0$ \\
\hline Agricultural Extension & $\$ 0$ & $\$ 0$ & $\$ 0$ & $\$ 0$ & $\$ 0$ \\
\hline Allied Clinics & $\$ 0$ & $\$ 0$ & $\$ 0$ & $\$ 0$ & $\$ 0$ \\
\hline Student Services & $\$ 936,353$ & $\$ 1,036,753$ & $\$ 1,053,402$ & $\$ 1,501,357$ & $\$ 1,501,267$ \\
\hline Intercollegiate Athletics & $\$ 0$ & $\$ 0$ & $\$ 0$ & $\$ 0$ & $\$ 0$ \\
\hline TOTAL & $\$ 31,912,018$ & $\$ 32,870,615$ & $\$ 32,220,288$ & $\$ 29,559,097$ & $\$ 38,555,247$ \\
\hline
\end{tabular}




\begin{tabular}{|c|c|c|c|c|c|}
\hline & 05-06 Actual & 06-07 Actual & 07-08 Actual & 08-09 Actual & $\begin{array}{c}2009-10 \\
\text { Estimates }\end{array}$ \\
\hline Contracts and Grants & & & & & \\
\hline Revenues & \multirow{2}{*}{\multicolumn{5}{|c|}{$\begin{array}{l}\text { Contracts \& Grants data is a USF system-wide function and consolidated ssystem } \\
\text { data is only available at this time. }\end{array}$}} \\
\hline Expenditures & & & & & \\
\hline \multicolumn{6}{|l|}{ Auxiliary Enterprises } \\
\hline Revenues & \multirow{2}{*}{\multicolumn{5}{|c|}{$\begin{array}{l}\text { Auxiliary Enterprise data is a USF system-wide function and consolidated ssystem } \\
\text { data is only available at this time. }\end{array}$}} \\
\hline Expenditures & & & & & \\
\hline \multicolumn{6}{|l|}{ Local Funds } \\
\hline Revenues & \multirow{2}{*}{\multicolumn{5}{|c|}{$\begin{array}{l}\text { Local Funds data is a USF system-wide function and consolidated ssystem data is } \\
\text { only available at this time. }\end{array}$}} \\
\hline Expenditures & & & & & \\
\hline
\end{tabular}

\begin{tabular}{|c|c|c|c|c|c|}
\hline TOTAL REVENUES & $\$ 35,913,481$ & $\$ 36,901,302$ & $\$ 37,755,521$ & $\$ 36,731,375$ & $\$ 38,555,247$ \\
\hline TOTAL EXPENDITURES & $\$ 31,912,018$ & $\$ 32,870,615$ & $\$ 32,220,288$ & $\$ 29,559,097$ & $\$ 38,555,247$ \\
\hline \multicolumn{6}{|c|}{2 - Federal Stimulus Dollars (ARRA) } \\
\hline & & & & \multicolumn{2}{|c|}{ Proposed 2009-10 } \\
\hline & & & & \multicolumn{2}{|c|}{ USF (No HSC) } \\
\hline \# Jobs Saved/Created & & & & \multicolumn{2}{|c|}{50.9} \\
\hline \multicolumn{6}{|c|}{ Proposed Operating Budget Detail } \\
\hline \multicolumn{4}{|c|}{ Jobs Saved/Created } & \multicolumn{2}{|c|}{$\$ 1,925,121$} \\
\hline \multicolumn{4}{|l|}{ Scholarships } & \multicolumn{2}{|c|}{0} \\
\hline \multicolumn{4}{|l|}{ Library Resources } & \multicolumn{2}{|c|}{0} \\
\hline \multicolumn{4}{|c|}{ Building Repairs/Alterations } & \multicolumn{2}{|c|}{0} \\
\hline \multicolumn{4}{|l|}{ Motor Vehicles } & \multicolumn{2}{|c|}{0} \\
\hline \multicolumn{4}{|l|}{ Printing } & \multicolumn{2}{|c|}{0} \\
\hline \multicolumn{4}{|l|}{ Furniture \& Equipment } & \multicolumn{2}{|c|}{0} \\
\hline \multicolumn{4}{|c|}{ Information Technology Equipment } & \multicolumn{2}{|c|}{0} \\
\hline \multicolumn{4}{|c|}{ Financial Aid to Medical Students } & \multicolumn{2}{|c|}{0} \\
\hline \multicolumn{4}{|c|}{ Other: } & \multicolumn{2}{|c|}{0} \\
\hline \multicolumn{4}{|l|}{ TOTAL } & \multicolumn{2}{|c|}{$\$ 1,925,121$} \\
\hline
\end{tabular}




\begin{tabular}{|c|c|c|c|c|c|}
\hline \multicolumn{6}{|c|}{1 - Budget (Special Units-Health Science Center) } \\
\hline & 2005-06 Actual & 2006-07 Actual & 2007-08 Actual & 2008-09 Actual & $\begin{array}{c}2009-10 \\
\text { Estimates }\end{array}$ \\
\hline Health Science Center & & & & & \\
\hline HSC Revenues & & & & & \\
\hline $\begin{array}{c}\text { State Funds (Recurring GR } \\
\text { \& Lottery) }\end{array}$ & \multirow{8}{*}{\multicolumn{5}{|c|}{ DATA ARE ONLY APPLICABLE TO USF TAMPA }} \\
\hline $\begin{array}{c}\text { State Funds (Non- } \\
\text { Recurring GR \& Lottery) }\end{array}$ & & & & & \\
\hline $\begin{array}{c}\text { Tuition (Resident/Non- } \\
\text { Resident) } \\
\end{array}$ & & & & & \\
\hline Tuition Differential (UG) & & & & & \\
\hline $\begin{array}{l}\text { Other (Include Revenues } \\
\text { from Misc. Fees \& Fines) }\end{array}$ & & & & & \\
\hline $\begin{array}{c}\text { Phosphate Research Trust } \\
\text { Fund } \\
\end{array}$ & & & & & \\
\hline Federal Stimulus Funds & & & & & \\
\hline TOTAL & & & & & \\
\hline & 2005-06 Actual & 2006-07 Actual & 2007-08 Actual & 2008-09 Actual & $\begin{array}{c}2009-10 \\
\text { Estimates }\end{array}$ \\
\hline HSC Expenditures & & & & & \\
\hline Instruction/Research & \multirow{12}{*}{\multicolumn{5}{|c|}{ DATA ARE ONLY APPLICABLE TO USF TAMPA }} \\
\hline $\begin{array}{c}\text { Institutes and Research } \\
\text { Centers }\end{array}$ & & & & & \\
\hline PO\&M & & & & & \\
\hline $\begin{array}{l}\text { Administration and } \\
\text { Support Services }\end{array}$ & & & & & \\
\hline Radio/TV & & & & & \\
\hline Library/Audio Visual & & & & & \\
\hline Museums and Galleries & & & & & \\
\hline Agricultural Extension & & & & & \\
\hline Allied Clinics & & & & & \\
\hline Student Services & & & & & \\
\hline Intercollegiate Athletics & & & & & \\
\hline TOTAL & & & & & \\
\hline
\end{tabular}




\begin{tabular}{|l|c|}
\hline \multicolumn{2}{|c|}{ 2 - Federal Stimulus Dollars (ARRA) } \\
\hline \multicolumn{1}{|c|}{} \\
\hline \# Jobs Saved/Created & \\
\hline Proposed Operating Budget Detail & \\
\hline Jobs Saved/Created & \\
\hline Scholarships & \\
\hline Library Resources & \\
\hline Building Repairs/Alterations & \\
\hline Motor Vehicles & \\
\hline Printing & \\
\hline Furniture \& Equipment & \\
\hline Information Technology Equipment & \\
\hline Financial Aid to Medical Students & \\
\hline Other: & \\
\hline TOTAL & \\
\hline
\end{tabular}




\begin{tabular}{|c|c|c|c|c|c|}
\hline \multicolumn{2}{|c|}{3 - Other Core Resources } \\
\hline $\begin{array}{c}\text { Funding per Student FTE } \\
\text { (US Definition) }\end{array}$ & $2005-06$ & $2006-07$ & $2007-08$ & $2008-09$ & $2009-10$ \\
\hline General Revenue per FTE & $\$ 9,759$ & $\$ 9,210$ & $\$ 8,661$ & $\$ 7,219$ & $\$ 6,277$ \\
\hline Lottery Funds per FTE & $\$ 229$ & $\$ 119$ & $\$ 116$ & $\$ 343$ & $\$ 253$ \\
\hline Other Trust Funds per FTE & $\$ 0$ & $\$ 0$ & $\$ 0$ & $\$ 0$ & $\$ 554$ \\
\hline Student Fees per FTE & $\$ 2,752$ & $\$ 2,859$ & $\$ 11,678$ & $\$ 10,662$ & $\$ 11,098$ \\
\hline Total per FTE Student & $\$ 12,740$ & $\$ 12,188$ & $\$ 4,015$ \\
\hline
\end{tabular}

** FTE for this metric uses the standard IPEDS definition of FTE, equal to 30 credit hours for undergraduates and 24 for graduates.

\begin{tabular}{|c|c|c|c|c|c|c|c|c|c|c|}
\hline \multirow{2}{*}{ Personnel Headcount } & \multicolumn{2}{|c|}{ Fall 2004} & \multicolumn{2}{|c|}{ Fall 2005} & \multicolumn{2}{|c|}{ Fall 2006} & \multicolumn{2}{|c|}{ Fall 2007} & \multicolumn{2}{|c|}{ Fall 2008} \\
\hline & FT & PT & FT & PT & FT & PT & FT & PT & FT & PT \\
\hline $\begin{array}{c}\text { Total Tenure/ Tenure-track } \\
\text { Faculty }\end{array}$ & 95 & 1 & 73 & 0 & 86 & 0 & 93 & 0 & 87 & 1 \\
\hline $\begin{array}{c}\text { Total Non-Tenure Track } \\
\text { Faculty }\end{array}$ & 30 & 7 & 36 & 5 & 34 & 5 & 35 & 4 & 26 & 8 \\
\hline $\begin{array}{c}\text { Total Graduate Assistants/ } \\
\text { Associates }\end{array}$ & & 26 & & 24 & & 20 & & 19 & & 20 \\
\hline $\begin{array}{l}\text { Total Executive/ Ad- } \\
\text { ministrative/ Managerial }\end{array}$ & 32 & 0 & 32 & 0 & 33 & 0 & 39 & 4 & 38 & 0 \\
\hline Total Other Professional & 66 & 0 & 68 & 34 & 78 & 3 & 64 & 6 & 67 & 2 \\
\hline Total Non-Professional & 89 & 2 & 92 & 1 & 100 & 0 & 109 & 0 & 92 & 4 \\
\hline Space & \multicolumn{2}{|c|}{ Fall 2004} & \multicolumn{2}{|c|}{ Fall 2005} & \multicolumn{2}{|c|}{ Fall 2006} & \multicolumn{2}{|c|}{ Fall 2007} & \multicolumn{2}{|c|}{ Fall 2008} \\
\hline $\begin{array}{c}\text { Space Utilization } \\
\text { Percentage (Classrooms) }\end{array}$ & \multicolumn{2}{|c|}{$\mathrm{N} / \mathrm{A}$} & \multicolumn{2}{|c|}{$\mathrm{N} / \mathrm{A}$} & \multicolumn{2}{|c|}{$\mathrm{N} / \mathrm{A}$} & \multicolumn{2}{|c|}{$\mathrm{N} / \mathrm{A}$} & \multicolumn{2}{|c|}{$84.85 \%$} \\
\hline
\end{tabular}




\begin{tabular}{|c|c|c|c|c|c|c|}
\hline \multicolumn{7}{|c|}{4 - Enrollment and Funding } \\
\hline $\begin{array}{c}\text { For entire } \\
\text { institution: } \\
\text { Annual FTE }\end{array}$ & $\begin{array}{l}\text { Funded } \\
2007-08\end{array}$ & $\begin{array}{r}2007-08 \\
\text { Actual }\end{array}$ & $\begin{array}{l}\text { Funded } \\
2008-09\end{array}$ & 2008-09 Actual & $\begin{array}{l}\text { Funded } \\
2009-10\end{array}$ & $\begin{array}{c}2009-10 \\
\text { Estimated }\end{array}$ \\
\hline $\begin{array}{l}\text { FL Resident } \\
\text { Lower }\end{array}$ & 657 & 641 & 657 & 725 & 657 & 750 \\
\hline $\begin{array}{c}\text { FL Resident } \\
\text { Upper }\end{array}$ & 1,486 & 1,479 & 1,486 & 1,522 & 1,486 & 1,500 \\
\hline $\begin{array}{c}\text { FL Resident } \\
\text { Grad I }\end{array}$ & 227 & 279 & 227 & 290 & 227 & 300 \\
\hline $\begin{array}{c}\text { FL Resident } \\
\text { Grad II }\end{array}$ & 0 & 4 & 0 & 1 & 0 & 0 \\
\hline $\begin{array}{c}\text { Total FL } \\
\text { Resident }\end{array}$ & 2,370 & 2,403 & 2,370 & 2,538 & 2,370 & 2,550 \\
\hline $\begin{array}{c}\text { Non-Res. } \\
\text { Lower }\end{array}$ & & 19 & & 16 & & 20 \\
\hline $\begin{array}{l}\text { Non-Res. } \\
\text { Upper }\end{array}$ & & 27 & & 26 & & 30 \\
\hline $\begin{array}{c}\text { Non-Res. Grad } \\
\text { I }\end{array}$ & & 6 & & 5 & & 5 \\
\hline $\begin{array}{c}\text { Non-Res. Grad } \\
\text { II } \\
\end{array}$ & & 0 & & 0 & & 0 \\
\hline Total Non-Res. & 52 & 52 & 52 & 47 & 52 & 55 \\
\hline Total Lower & & 660 & & 741 & & 770 \\
\hline Total Upper & & 1,506 & & 1,547 & & 1,530 \\
\hline Total Grad I & & 285 & & 296 & & 305 \\
\hline Total Grad II & & 4 & & 1 & & 0 \\
\hline Total FTE & 2,422 & 2,454 & 2,422 & 2,585 & 2,422 & 2,605 \\
\hline $\begin{array}{c}\text { Total FTE - US } \\
\text { Definition* }\end{array}$ & 3,232 & 3,275 & 3,232 & 3,446 & 3,232 & 3,474 \\
\hline
\end{tabular}




\begin{tabular}{|c|c|c|c|c|c|c|}
\hline Annual FTE & $\begin{array}{l}\text { Funded } \\
2007-08 \\
\end{array}$ & $\begin{array}{l}2007-08 \\
\text { Actual } \\
\end{array}$ & $\begin{array}{l}\text { Funded } \\
2008-09\end{array}$ & $\begin{array}{l}2008-09 \\
\text { Actual } \\
\end{array}$ & $\begin{array}{l}\text { Funded } \\
2009-10\end{array}$ & $\begin{array}{c}2009-10 \\
\text { Estimated }\end{array}$ \\
\hline $\begin{array}{c}\text { FL Resident } \\
\text { Medical } \\
\text { Headcount } \\
\end{array}$ & $\mathrm{N} / \mathrm{A}$ & $\mathrm{N} / \mathrm{A}$ & $\mathrm{N} / \mathrm{A}$ & $\mathrm{N} / \mathrm{A}$ & $\mathrm{N} / \mathrm{A}$ & $\mathrm{N} / \mathrm{A}$ \\
\hline $\begin{array}{c}\text { Non-Res. } \\
\text { Medical } \\
\text { Headcount } \\
\end{array}$ & & $\mathrm{N} / \mathrm{A}$ & & $\mathrm{N} / \mathrm{A}$ & & $\mathrm{N} / \mathrm{A}$ \\
\hline $\begin{array}{c}\text { Total Medical } \\
\text { Headcount }\end{array}$ & & $\mathrm{N} / \mathrm{A}$ & & $\mathrm{N} / \mathrm{A}$ & & N/A \\
\hline $\begin{array}{l}\text { FL Resident } \\
\text { Dentistry } \\
\text { Headcount }\end{array}$ & $\mathrm{N} / \mathrm{A}$ & $\mathrm{N} / \mathrm{A}$ & $\mathrm{N} / \mathrm{A}$ & $\mathrm{N} / \mathrm{A}$ & $\mathrm{N} / \mathrm{A}$ & N/A \\
\hline $\begin{array}{c}\text { Non-Res. } \\
\text { Dentistry } \\
\text { Headcount } \\
\end{array}$ & & $\mathrm{N} / \mathrm{A}$ & & N/A & & N/A \\
\hline $\begin{array}{c}\text { Total Dentistry } \\
\text { Headcount }\end{array}$ & & $\mathrm{N} / \mathrm{A}$ & & $\mathrm{N} / \mathrm{A}$ & & N/A \\
\hline $\begin{array}{l}\text { FL Resident } \\
\text { Veterinary } \\
\text { Medicine } \\
\text { Headcount }\end{array}$ & $\mathrm{N} / \mathrm{A}$ & $\mathrm{N} / \mathrm{A}$ & $\mathrm{N} / \mathrm{A}$ & $\mathrm{N} / \mathrm{A}$ & $\mathrm{N} / \mathrm{A}$ & $\mathrm{N} / \mathrm{A}$ \\
\hline $\begin{array}{c}\text { Non-Res. } \\
\text { Veterinary } \\
\text { Medicine } \\
\text { Headcount }\end{array}$ & & $\mathrm{N} / \mathrm{A}$ & & $\mathrm{N} / \mathrm{A}$ & & N/A \\
\hline $\begin{array}{c}\text { Total } \\
\text { Veterinary } \\
\text { Medicine } \\
\text { Headcount } \\
\end{array}$ & & $\mathrm{N} / \mathrm{A}$ & & N/A & & N/A \\
\hline $\begin{array}{l}\text { Total Non-Res. } \\
\text { Med., Den., } \\
\text { Vet. Medicine } \\
\text { Headcount }\end{array}$ & $\mathrm{N} / \mathrm{A}$ & $\mathrm{N} / \mathrm{A}$ & $\mathrm{N} / \mathrm{A}$ & $\mathrm{N} / \mathrm{A}$ & N/A & $\mathrm{N} / \mathrm{A}$ \\
\hline
\end{tabular}




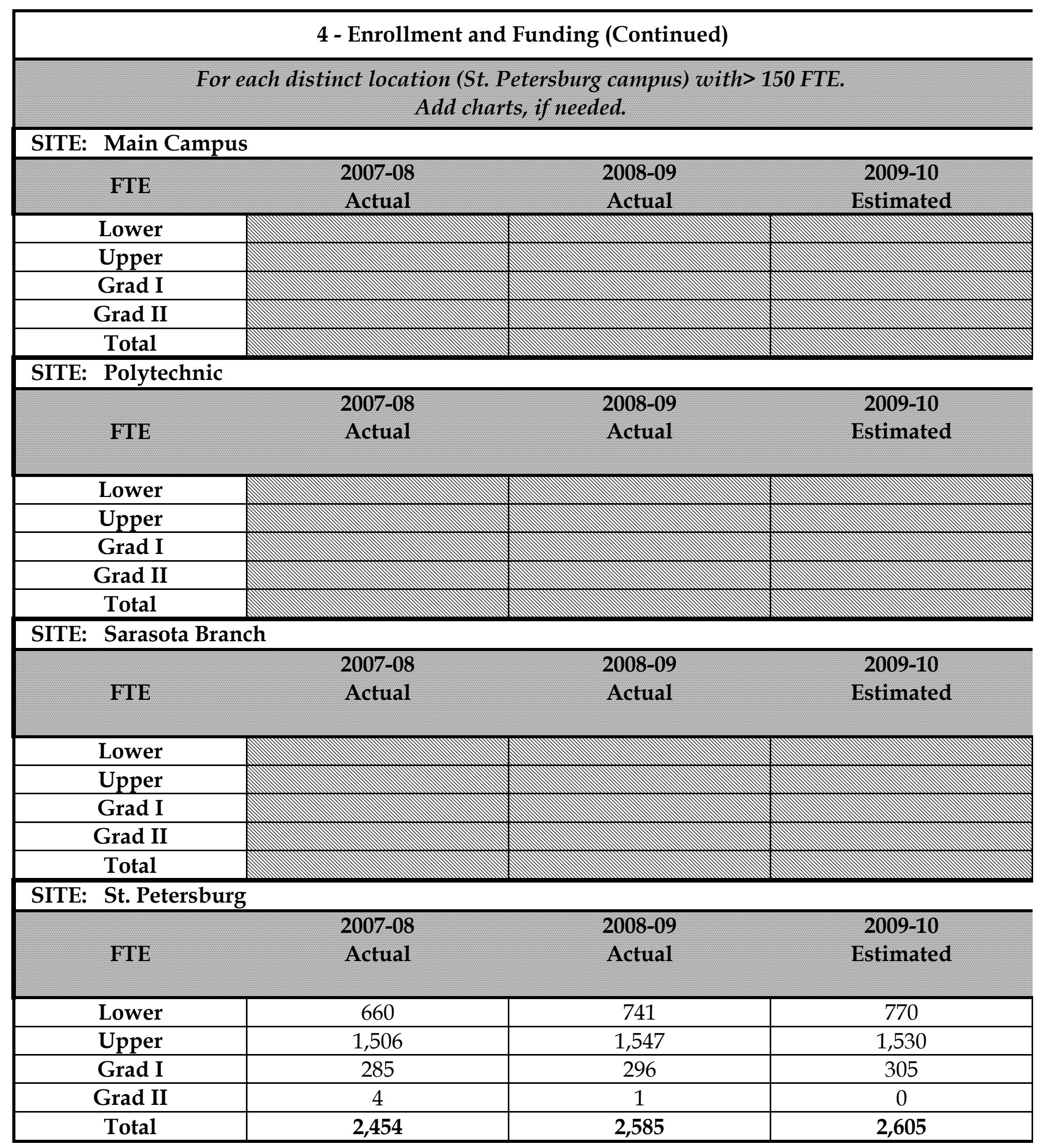


4 - Enrollment and Funding (Continued)

(1)




\begin{tabular}{|c|c|c|c|c|c|}
\hline \multicolumn{6}{|c|}{5 - Undergraduate Education Data } \\
\hline $\begin{array}{l}\text { 5A. Baccalaureate } \\
\text { Degree Programs } \\
\text { Implemented or } \\
\text { Terminated }\end{array}$ & \multirow{2}{*}{$\begin{array}{l}\text { New } \\
\text { Program or } \\
\text { Termina- } \\
\text { tion? }\end{array}$} & \multirow{2}{*}{$\begin{array}{l}\text { Date } \\
\text { Approved } \\
\text { by UBOT }\end{array}$} & \multirow{2}{*}{$\begin{array}{l}\text { Date } \\
\text { Approved } \\
\text { by BOG, if } \\
\text { Needed }\end{array}$} & \multirow[t]{2}{*}{$\begin{array}{l}\text { Implementa- } \\
\text { tion Date, if } \\
\text { New }\end{array}$} & \multirow[t]{2}{*}{$\begin{array}{c}\text { Program CIP } \\
\text { Code }\end{array}$} \\
\hline Title and Program Level & & & & & \\
\hline $\begin{array}{c}\text { Education, Multi-Cert (St. } \\
\text { Pete) }\end{array}$ & New & $6 / 12 / 2008$ & $\mathrm{n} / \mathrm{a}$ & Fall 2008 & 13.1206 \\
\hline Graphic Design & New & $7 / 16 / 2008$ & $\mathrm{n} / \mathrm{a}$ & Fall 2008 & 50.0409 \\
\hline \multicolumn{6}{|c|}{ 5B. Successful First-Year Persistence Rates } \\
\hline $\begin{array}{c}\text { YEAR OF SUS } \\
\text { MATRICULATION }\end{array}$ & 2003 & 2004 & 2005 & 2006 & 2007 \\
\hline $\begin{array}{l}\text { Full-Time FTIC Cohort } \\
\text { (Fall/Summer-Fall) Size }\end{array}$ & 228 & 169 & 179 & 274 & 233 \\
\hline $\begin{array}{c}\text { Percentage Enrolled in } \\
\text { Same IHE After One } \\
\text { Year }\end{array}$ & $84.00 \%$ & $84.00 \%$ & $81.00 \%$ & $80.00 \%$ & 86 \\
\hline
\end{tabular}




\begin{tabular}{|c|c|c|c|c|c|}
\hline \multicolumn{6}{|c|}{ 5C. Successful Undergraduate Progression and Graduation Rates } \\
\hline $\begin{array}{c}\text { YEAR OF SUS } \\
\text { MATRICULATION } \\
\end{array}$ & 1999 & 2000 & 2001 & 2002 & 2003 \\
\hline $\begin{array}{c}\text { FTIC Cohort } \\
\text { (Fall/Summer-Fall) Size }\end{array}$ & $\mathrm{N} / \mathrm{A}$ & $\mathrm{N} / \mathrm{A}$ & $\mathrm{N} / \mathrm{A}$ & $\mathrm{N} / \mathrm{A}$ & $\mathrm{N} / \mathrm{A}$ \\
\hline $\begin{array}{c}\text { Percentage Graduated } \\
\text { from Same IHE Within } 4 \\
\text { Years }\end{array}$ & $\mathrm{N} / \mathrm{A}$ & $\mathrm{N} / \mathrm{A}$ & $\mathrm{N} / \mathrm{A}$ & $\mathrm{N} / \mathrm{A}$ & $\mathrm{N} / \mathrm{A}$ \\
\hline $\begin{array}{c}\text { Percentage Graduated } \\
\text { from Other SUS IHE } \\
\text { Within } 4 \text { Years } \\
\end{array}$ & $\mathrm{N} / \mathrm{A}$ & $\mathrm{N} / \mathrm{A}$ & $\mathrm{N} / \mathrm{A}$ & $\mathrm{N} / \mathrm{A}$ & $\mathrm{N} / \mathrm{A}$ \\
\hline $\begin{array}{l}\text { Percentage Enrolled in } \\
\text { Same IHE After } 4 \text { Years }\end{array}$ & $\mathrm{N} / \mathrm{A}$ & $\mathrm{N} / \mathrm{A}$ & $\mathrm{N} / \mathrm{A}$ & $\mathrm{N} / \mathrm{A}$ & $\mathrm{N} / \mathrm{A}$ \\
\hline $\begin{array}{c}\text { Percentage Enrolled in } \\
\text { Other SUS IHE After } 4 \\
\text { Years }\end{array}$ & $\mathrm{N} / \mathrm{A}$ & $\mathrm{N} / \mathrm{A}$ & $\mathrm{N} / \mathrm{A}$ & $\mathrm{N} / \mathrm{A}$ & $\mathrm{N} / \mathrm{A}$ \\
\hline $\begin{array}{c}\text { TOTAL 4-Year Success } \\
\text { and Progress Rate } \\
\text { (Graduated or Enrolled } \\
\text { in SUS) }\end{array}$ & $\mathrm{N} / \mathrm{A}$ & $\mathrm{N} / \mathrm{A}$ & $\mathrm{N} / \mathrm{A}$ & $\mathrm{N} / \mathrm{A}$ & $\mathrm{N} / \mathrm{A}$ \\
\hline $\begin{array}{c}\text { Percentage Graduated } \\
\text { from Same IHE Within } 6 \\
\text { Years }\end{array}$ & $\mathrm{N} / \mathrm{A}$ & $\mathrm{N} / \mathrm{A}$ & $\mathrm{N} / \mathrm{A}$ & $\mathrm{N} / \mathrm{A}$ & $\mathrm{N} / \mathrm{A}$ \\
\hline $\begin{array}{c}\text { Percentage Graduated } \\
\text { from Other SUS IHE } \\
\text { Within } 6 \text { Years } \\
\end{array}$ & $\mathrm{N} / \mathrm{A}$ & $\mathrm{N} / \mathrm{A}$ & $\mathrm{N} / \mathrm{A}$ & $\mathrm{N} / \mathrm{A}$ & $\mathrm{N} / \mathrm{A}$ \\
\hline $\begin{array}{l}\text { Percentage Enrolled in } \\
\text { Same IHE After } 6 \text { Years }\end{array}$ & $\mathrm{N} / \mathrm{A}$ & $\mathrm{N} / \mathrm{A}$ & $\mathrm{N} / \mathrm{A}$ & $\mathrm{N} / \mathrm{A}$ & $\mathrm{N} / \mathrm{A}$ \\
\hline $\begin{array}{c}\text { Percentage Enrolled in } \\
\text { Other SUS IHE After } 6 \\
\text { Years }\end{array}$ & $\mathrm{N} / \mathrm{A}$ & $\mathrm{N} / \mathrm{A}$ & $\mathrm{N} / \mathrm{A}$ & $\mathrm{N} / \mathrm{A}$ & $\mathrm{N} / \mathrm{A}$ \\
\hline $\begin{array}{c}\text { TOTAL 6-Year Success } \\
\text { and Progress Rate } \\
\text { (Graduated or Enrolled } \\
\text { in SUS) }\end{array}$ & $\mathrm{N} / \mathrm{A}$ & $\mathrm{N} / \mathrm{A}$ & $\mathrm{N} / \mathrm{A}$ & $\mathrm{N} / \mathrm{A}$ & $\mathrm{N} / \mathrm{A}$ \\
\hline
\end{tabular}




\begin{tabular}{|c|c|c|c|c|c|}
\hline $\begin{array}{c}\text { YEAR OF SUS } \\
\text { MATRICULATION }\end{array}$ & 2001 & 2002 & 2003 & 2004 & 2005 \\
\hline $\begin{array}{c}\text { AA Transfer Cohort } \\
\text { (Fall/Summer-Fall) Size }\end{array}$ & $\mathrm{N} / \mathrm{A}$ & $\mathrm{N} / \mathrm{A}$ & $\mathrm{N} / \mathrm{A}$ & $\mathrm{N} / \mathrm{A}$ & $\mathrm{N} / \mathrm{A}$ \\
\hline $\begin{array}{c}\text { Percentage Graduated } \\
\text { from Same IHE Within } 2 \\
\text { Years }\end{array}$ & $\mathrm{N} / \mathrm{A}$ & $\mathrm{N} / \mathrm{A}$ & $\mathrm{N} / \mathrm{A}$ & $\mathrm{N} / \mathrm{A}$ & $\mathrm{N} / \mathrm{A}$ \\
\hline $\begin{array}{c}\text { Percentage Graduated } \\
\text { from Other SUS IHE } \\
\text { Within } 2 \text { Years }\end{array}$ & $\mathrm{N} / \mathrm{A}$ & $\mathrm{N} / \mathrm{A}$ & $\mathrm{N} / \mathrm{A}$ & $\mathrm{N} / \mathrm{A}$ & $\mathrm{N} / \mathrm{A}$ \\
\hline $\begin{array}{l}\text { Percentage Enrolled in } \\
\text { Same IHE After } 2 \text { Years }\end{array}$ & $\mathrm{N} / \mathrm{A}$ & $\mathrm{N} / \mathrm{A}$ & $\mathrm{N} / \mathrm{A}$ & $\mathrm{N} / \mathrm{A}$ & $\mathrm{N} / \mathrm{A}$ \\
\hline $\begin{array}{c}\text { Percentage Enrolled in } \\
\text { Other SUS IHE After } 2 \\
\text { Years }\end{array}$ & $\mathrm{N} / \mathrm{A}$ & $\mathrm{N} / \mathrm{A}$ & $\mathrm{N} / \mathrm{A}$ & $\mathrm{N} / \mathrm{A}$ & $\mathrm{N} / \mathrm{A}$ \\
\hline $\begin{array}{c}\text { TOTAL 2-Year Success } \\
\text { and Progress Rate } \\
\text { (Graduated or Enrolled } \\
\text { in SUS) }\end{array}$ & $\mathrm{N} / \mathrm{A}$ & $\mathrm{N} / \mathrm{A}$ & $\mathrm{N} / \mathrm{A}$ & $\mathrm{N} / \mathrm{A}$ & $\mathrm{N} / \mathrm{A}$ \\
\hline $\begin{array}{c}\text { Percentage Graduated } \\
\text { from Same IHE Within } 4 \\
\text { Years }\end{array}$ & $\mathrm{N} / \mathrm{A}$ & $\mathrm{N} / \mathrm{A}$ & $\mathrm{N} / \mathrm{A}$ & $\mathrm{N} / \mathrm{A}$ & $\mathrm{N} / \mathrm{A}$ \\
\hline $\begin{array}{c}\text { Percentage Graduated } \\
\text { from Other SUS IHE } \\
\text { Within } 4 \text { Years }\end{array}$ & $\mathrm{N} / \mathrm{A}$ & $\mathrm{N} / \mathrm{A}$ & $\mathrm{N} / \mathrm{A}$ & $\mathrm{N} / \mathrm{A}$ & $\mathrm{N} / \mathrm{A}$ \\
\hline $\begin{array}{l}\text { Percentage Enrolled in } \\
\text { Same IHE After } 4 \text { Years }\end{array}$ & $\mathrm{N} / \mathrm{A}$ & $\mathrm{N} / \mathrm{A}$ & $\mathrm{N} / \mathrm{A}$ & $\mathrm{N} / \mathrm{A}$ & $\mathrm{N} / \mathrm{A}$ \\
\hline $\begin{array}{c}\text { Percentage Enrolled in } \\
\text { Other SUS IHE After } 4 \\
\text { Years }\end{array}$ & $\mathrm{N} / \mathrm{A}$ & $\mathrm{N} / \mathrm{A}$ & $\mathrm{N} / \mathrm{A}$ & $\mathrm{N} / \mathrm{A}$ & $\mathrm{N} / \mathrm{A}$ \\
\hline $\begin{array}{c}\text { TOTAL 4-Year Success } \\
\text { and Progress Rate } \\
\text { (Graduated or Enrolled } \\
\text { in SUS) }\end{array}$ & $\mathrm{N} / \mathrm{A}$ & $\mathrm{N} / \mathrm{A}$ & $\mathrm{N} / \mathrm{A}$ & $\mathrm{N} / \mathrm{A}$ & $\mathrm{N} / \mathrm{A}$ \\
\hline
\end{tabular}




\begin{tabular}{|c|c|c|c|c|c|}
\hline YEAR OF SUS MATRIC. & 2000 & 2001 & 2002 & 2003 & 2004 \\
\hline $\begin{array}{l}\text { Other Transfer Cohort } \\
\text { (Fall/Summer-Fall) Size }\end{array}$ & $\mathrm{N} / \mathrm{A}$ & $\mathrm{N} / \mathrm{A}$ & $\mathrm{N} / \mathrm{A}$ & $\mathrm{N} / \mathrm{A}$ & $\mathrm{N} / \mathrm{A}$ \\
\hline $\begin{array}{c}\text { Percentage Graduated } \\
\text { from Same IHE Within } 5 \\
\text { Years }\end{array}$ & $\mathrm{N} / \mathrm{A}$ & $\mathrm{N} / \mathrm{A}$ & $\mathrm{N} / \mathrm{A}$ & $\mathrm{N} / \mathrm{A}$ & $\mathrm{N} / \mathrm{A}$ \\
\hline $\begin{array}{c}\text { Percentage Graduated } \\
\text { from Other SUS IHE } \\
\text { Within } 5 \text { Years }\end{array}$ & $\mathrm{N} / \mathrm{A}$ & $\mathrm{N} / \mathrm{A}$ & $\mathrm{N} / \mathrm{A}$ & $\mathrm{N} / \mathrm{A}$ & $\mathrm{N} / \mathrm{A}$ \\
\hline $\begin{array}{l}\text { Percentage Enrolled in } \\
\text { Same IHE After } 5 \text { Years }\end{array}$ & $\mathrm{N} / \mathrm{A}$ & $\mathrm{N} / \mathrm{A}$ & $\mathrm{N} / \mathrm{A}$ & $\mathrm{N} / \mathrm{A}$ & $\mathrm{N} / \mathrm{A}$ \\
\hline $\begin{array}{c}\text { Percentage Enrolled in } \\
\text { Other SUS IHE After } 5 \\
\text { Years }\end{array}$ & $\mathrm{N} / \mathrm{A}$ & $\mathrm{N} / \mathrm{A}$ & $\mathrm{N} / \mathrm{A}$ & $\mathrm{N} / \mathrm{A}$ & $\mathrm{N} / \mathrm{A}$ \\
\hline $\begin{array}{c}\text { TOTAL 5-Year Success } \\
\text { and Progress Rate } \\
\text { (Graduated or Enrolled } \\
\text { in SUS) }\end{array}$ & $\mathrm{N} / \mathrm{A}$ & $\mathrm{N} / \mathrm{A}$ & $\mathrm{N} / \mathrm{A}$ & $\mathrm{N} / \mathrm{A}$ & $\mathrm{N} / \mathrm{A}$ \\
\hline $\begin{array}{l}\text { 5D. Baccalaureate } \\
\text { Degrees Awarded }\end{array}$ & 2004-2005 & 2005-2006 & 2006-2007 & 2007-2008 & 2008-2009 \\
\hline Baccalaureate Degrees & 661 & 636 & 647 & 668 & 657 \\
\hline $\begin{array}{l}\text { 5E. Baccalaureate } \\
\text { Degrees Awarded in }\end{array}$ & \multicolumn{5}{|c|}{$\begin{array}{l}\text { Areas of Strategic Emphasis: Specific degree programs will be } \\
\text { identified for each university. [UNDUPLICATED COUNT] }\end{array}$} \\
\hline Emphasis & 2004-2005 & 2005-2006 & 2006-2007 & 2007-2008 & 2008-2009 \\
\hline Education & 19 & 16 & 18 & 12 & 15 \\
\hline Health Professions & 1 & 0 & 0 & 0 & 0 \\
\hline $\begin{array}{l}\text { Science, Technology, } \\
\text { Engineering, and Math }\end{array}$ & 50 & 42 & 26 & 30 & 30 \\
\hline $\begin{array}{l}\text { Security \& Emergency } \\
\text { Services } \\
\end{array}$ & 48 & 45 & 35 & 39 & 38 \\
\hline Globalization & 27 & 32 & 29 & 41 & 37 \\
\hline $\begin{array}{l}\text { Regional Workforce } \\
\text { Needs }\end{array}$ & 195 & 203 & 219 & 224 & 227 \\
\hline $\begin{array}{l}\text { TOTAL: Areas of } \\
\text { Strategic Emphasis }\end{array}$ & 340 & 338 & 327 & 346 & 347 \\
\hline
\end{tabular}




\begin{tabular}{|c|c|c|c|c|c|}
\hline $\begin{array}{c}\text { 5F. Baccalaureate } \\
\text { Degrees Awarded to } \\
\text { Underrepresented } \\
\text { Groups }\end{array}$ & 2004-2005 & 2005-2006 & 2006-2007 & 2007-2008 & 2008-2009 \\
\hline $\begin{array}{c}\text { \# of Baccalaureate } \\
\text { Degrees Awarded to } \\
\text { Black Non-Hispanic } \\
\text { Students }\end{array}$ & 47 & 35 & 38 & 35 & 45 \\
\hline $\begin{array}{l}\% \text { of Total Baccalaureate } \\
\text { Degrees (Excluding } \\
\text { Those Awarded to Non- } \\
\text { Resident Aliens and } \\
\text { Unreported) Awarded to } \\
\text { Black Non-Hispanic } \\
\text { Students }\end{array}$ & $7.5 \%$ & $5.8 \%$ & $6.2 \%$ & $5.4 \%$ & $7.00 \%$ \\
\hline $\begin{array}{l}\text { \# of Baccalaureate } \\
\text { Degrees Awarded to } \\
\text { Hispanic Students }\end{array}$ & 39 & 39 & 29 & 45 & 52 \\
\hline $\begin{array}{l}\% \text { of Total Baccalaureate } \\
\text { Degrees (Excluding } \\
\text { Those Awarded to Non- } \\
\text { Resident Aliens and } \\
\text { Unreported) Awarded to } \\
\text { Hispanic Students }\end{array}$ & $6.2 \%$ & $6.4 \%$ & $4.7 \%$ & $7.0 \%$ & $8.1 \%$ \\
\hline $\begin{array}{l}\text { Number of Baccalaureate } \\
\text { Degrees Awarded to } \\
\text { PELL Recipients } \\
\text { (Defined as Those } \\
\text { Receiving PELL Within } 6 \\
\text { Years of Graduation) }\end{array}$ & 286 & 244 & 239 & 230 & 243 \\
\hline $\begin{array}{l}\% \text { of Total Baccalaureate } \\
\text { Degrees (Excluding } \\
\text { Those Awarded to Non- } \\
\text { Resident Aliens) } \\
\text { Awarded to PELL } \\
\text { Recipients (Defined as } \\
\text { Those Receiving PELL } \\
\text { Within } 6 \text { Years of } \\
\text { Graduation) }\end{array}$ & $45.8 \%$ & $40.3 \%$ & $40.0 \%$ & $35.7 \%$ & $37.9 \%$ \\
\hline
\end{tabular}




\begin{tabular}{|c|c|c|c|c|c|}
\hline $\begin{array}{l}\text { 5G. Baccalaureate } \\
\text { Completion Without } \\
\text { Excess Credit Hours }\end{array}$ & 2004-2005 & 2005-2006 & 2006-2007 & 2007-2008 & 2008-2009 \\
\hline $\begin{array}{c}\% \text { of Total Baccalaureate } \\
\text { Degrees Awarded } \\
\text { Within } 110 \% \text { of Hours } \\
\text { Required for Degree }\end{array}$ & $\mathrm{N} / \mathrm{A}$ & $\mathrm{N} / \mathrm{A}$ & $\mathrm{N} / \mathrm{A}$ & $50.81 \%$ & $50.59 \%$ \\
\hline $\begin{array}{l}\text { 5H. Undergraduate } \\
\text { Course Offerings }\end{array}$ & Fall 2004 & Fall 2005 & Fall 2006 & Fall 2007 & Fall 2008 \\
\hline $\begin{array}{c}\text { Number of } \\
\text { Undergraduate Course } \\
\text { Sections }\end{array}$ & 370 & 376 & 390 & 378 & 342 \\
\hline $\begin{array}{c}\text { \% of Undergraduate } \\
\text { Course Sections With < } \\
30 \text { Students }\end{array}$ & $59.5 \%$ & $59.0 \%$ & $60.5 \%$ & $58.5 \%$ & $54.7 \%$ \\
\hline $\begin{array}{l}\% \text { of Undergraduate } \\
\text { Course Sections With } \\
>=30 \text { and }<50 \text { Students }\end{array}$ & $33.7 \%$ & $35.6 \%$ & $33.9 \%$ & $35.9 \%$ & $34.2 \%$ \\
\hline $\begin{array}{c}\% \text { of Undergraduate } \\
\text { Course Sections With } \\
>=50 \text { and }<100 \text { Students }\end{array}$ & $6.8 \%$ & $5.4 \%$ & $5.6 \%$ & $5.6 \%$ & $10.8 \%$ \\
\hline $\begin{array}{l}\% \text { of Undergraduate } \\
\text { Course Sections With } \\
>=100 \text { Students }\end{array}$ & $0.0 \%$ & $0.0 \%$ & $0.0 \%$ & $0.0 \%$ & $0.3 \%$ \\
\hline $\begin{array}{l}\text { 5I. Faculty Teaching } \\
\text { Undergraduates }\end{array}$ & 2004-2005 & 2005-2006 & 2006-2007 & 2007-2008 & 2008-2009 \\
\hline $\begin{array}{c}\text { Percentage of Credit } \\
\text { Hours Taught by Faculty }\end{array}$ & $71.8 \%$ & $64.7 \%$ & $67.4 \%$ & $71.1 \%$ & $67.9 \%$ \\
\hline $\begin{array}{c}\text { Percentage of Credit } \\
\text { Hours Taught by } \\
\text { Adjunct Faculty }\end{array}$ & $27.5 \%$ & $34.7 \%$ & $31.6 \%$ & $27.8 \%$ & $31.4 \%$ \\
\hline $\begin{array}{l}\text { Percentage of Credit } \\
\text { Hours Taught by } \\
\text { Graduate Students }\end{array}$ & $0.4 \%$ & $0.1 \%$ & $0.7 \%$ & $0.2 \%$ & $0.5 \%$ \\
\hline $\begin{array}{l}\text { Percentage of Credit } \\
\text { Hours Taught by Other } \\
\text { Instructors }\end{array}$ & $0.3 \%$ & $0.5 \%$ & $0.3 \%$ & $0.9 \%$ & $0.2 \%$ \\
\hline
\end{tabular}




\begin{tabular}{|c|c|c|c|c|c|}
\hline $\begin{array}{l}\text { 5J. Undergraduate } \\
\text { Instructional Faculty } \\
\text { Compensation }\end{array}$ & Fall 2004 & Fall 2005 & Fall 2006 & Fall 2007 & Fall 2008 \\
\hline $\begin{array}{c}\text { Average Salary and } \\
\text { Benefits for Faculty Who } \\
\text { Teach at Least One } \\
\text { Undergraduate Course }\end{array}$ & $\$ 80,007$ & $\$ 80,933$ & $\$ 83,146$ & $\$ 89,120$ & $\$ 91,252$ \\
\hline $\begin{array}{l}\text { 5K. Student/Faculty } \\
\text { Ratio }\end{array}$ & 2004-2005 & 2005-2006 & 2006-2007 & 2007-2008 & 2008-2009 \\
\hline $\begin{array}{c}\text { IPEDS/Common Data } \\
\text { Set Student-to-Faculty } \\
\text { Ratio }\end{array}$ & 19 & 17 & 19 & 19 & 22 \\
\hline 5L. Licensure Pass Rates & 2004 & 2005 & 2006 & 2007 & 2008 \\
\hline $\begin{array}{l}\text { Nursing: Number of } \\
\text { NCLEX First-Time Test } \\
\text { Takers - Baccalaureate }\end{array}$ & 0 & 0 & 0 & 0 & 0 \\
\hline $\begin{array}{l}\text { Nursing: Pass Rate for } \\
\text { NCLEX First-Time Test } \\
\text { Takers - Baccalaureate }\end{array}$ & $\mathrm{N} / \mathrm{A}$ & $\mathrm{N} / \mathrm{A}$ & $\mathrm{N} / \mathrm{A}$ & $\mathrm{N} / \mathrm{A}$ & $\mathrm{N} / \mathrm{A}$ \\
\hline \multicolumn{6}{|c|}{$\begin{array}{l}\text { Indicators for pass rates on other licensure exams will be added as data become available. } \\
\text { [See ENDNOTES.] }\end{array}$} \\
\hline
\end{tabular}




\begin{tabular}{|c|c|c|}
\hline 5M. Tuition Differential & 2008-2009 & $\begin{array}{l}\text { Sum-Fall } \\
2009\end{array}$ \\
\hline \multicolumn{3}{|l|}{ Revenues } \\
\hline Total Revenues Generated By the Tuition Differential & 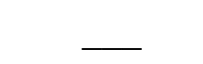 & \\
\hline \multicolumn{3}{|l|}{ Waivers } \\
\hline $\begin{array}{l}\text { Number of Students Eligible for Waiver Based on FSAG } \\
\text { Eligibility }\end{array}$ & 0 & 0 \\
\hline $\begin{array}{c}\text { Number of Students Receiving a Waiver Based on FSAG } \\
\text { Eligibility }\end{array}$ & 0 & 0 \\
\hline Value of Waivers Provided Based on FSAG Eligibility & 0 & 0 \\
\hline
\end{tabular}

Report on the success of the tuition differential in achieving the articulated purpose. Include an update on any performance measures that were specified in the BOG-approved tuition differential proposal. [NOTE: In 2009, universities will only be able to report progress for the fall term and reiterate how the university will monitor the long-term success of the tuition differential.]

The institution proposed to use the Tuition Differential funds to:

1. Hire faculty in two programs that are of high strategic importance.

2. Provide additional support for the Office of Registration and Records to assure that students are better served (recognizing the increased enrollment and increased demand on this office).

3. Provide an additional academic advisor for freshmen to recognize the greatly increased number of freshmen enrolling at USFSP over the past several years.

4. Provide additional support to colleges and departments and other student support units as appropriate for student academic support as needed and as appropriate.

Progress is as follows:

1. Faculty have been hired in both programs for the Fall 2009 term.

2. An additional staff member has been deployed to the Office of Registration and Records to provide increased service levels to students and other institutional constituencies. In addition, the Office was assigned a high priority in the deployment of Federal Work Study students (the demand for student workers vastly outstripped the funding available) 3. An additional freshmen advisor has been hired and another staff member has also been redeployed to the Office of Academic Advising to assist with student advising in pre-health professions and other high-demand majors.

4. Funds have been allocated to increase support services for physically challenged students.

Detailed expenditures of the revenues generated by the tuition differential will be captured in the Operating Budget submission each August. 


\section{6 - Graduate Education Data}

\begin{tabular}{|c|c|c|c|c|c|}
\hline $\begin{array}{l}\text { 6A. GraduateDegree Programs } \\
\text { Implemented or Terminated }\end{array}$ & \multirow{2}{*}{$\begin{array}{c}\text { New } \\
\text { Program or } \\
\text { Termina- } \\
\text { tion? }\end{array}$} & \multirow{2}{*}{$\begin{array}{l}\text { Date } \\
\text { Approved by } \\
\text { UBOT }\end{array}$} & \multirow{2}{*}{$\begin{array}{l}\text { Date } \\
\text { Approved by } \\
\text { BOG, if } \\
\text { Needed }\end{array}$} & \multirow{2}{*}{$\begin{array}{c}\text { Implementa- } \\
\text { tion Date, if } \\
\text { New }\end{array}$} & \multirow{2}{*}{$\begin{array}{l}\text { Program CIP } \\
\text { Code }\end{array}$} \\
\hline Title and Program Level & & & & & \\
\hline \multicolumn{6}{|l|}{$\mathrm{N} / \mathrm{A}$} \\
\hline 6B. Graduate Degrees Awarded & 2004-2005 & 2005-2006 & 2006-2007 & 2007-2008 & 2008-2009 \\
\hline Master's and Specialist & 144 & 120 & 144 & 125 & 158 \\
\hline Research Doctoral (Total) & 0 & 0 & 0 & 0 & 0 \\
\hline Professional Doctoral (Total) & 0 & 0 & 0 & 0 & 0 \\
\hline Medicine & 0 & 0 & 0 & 0 & 0 \\
\hline Law & 0 & 0 & 0 & 0 & 0 \\
\hline Pharmacy & 0 & 0 & 0 & 0 & 0 \\
\hline \multirow{2}{*}{$\begin{array}{l}\text { 6C. Graduate Degrees Awarded in } \\
\text { Areas of Strategic Emphasis }\end{array}$} & \multicolumn{5}{|c|}{ Areas of Strategic Emphasis: Specific degree programs will be identified } \\
\hline & 2004-2005 & $2005-2006$ & 2006-2007 & $2007-2008$ & 2008-2009 \\
\hline Education & 16 & 38 & 69 & 59 & 54 \\
\hline Health Professions & 0 & 0 & 0 & 0 & 0 \\
\hline $\begin{array}{c}\text { Science, Technology, Engineering, } \\
\text { and Math }\end{array}$ & 10 & 0 & 8 & 8 & 1 \\
\hline Security \& Emergency Services & 0 & 0 & 0 & 0 & 0 \\
\hline Globalization & 1 & 0 & 0 & 0 & 0 \\
\hline Regional Workforce Needs & 3 & 15 & 33 & 26 & 45 \\
\hline $\begin{array}{c}\text { TOTAL: Areas of Strategic } \\
\text { Emphasis }\end{array}$ & 30 & 53 & 110 & 93 & 100 \\
\hline 6D. Licensure Pass Rates & 2004 & 2005 & 2006 & 2007 & 2008 \\
\hline
\end{tabular}




\section{7 - Research and Economic Development Data}

\begin{tabular}{|c|}
\hline 7A. Research and Development \\
Expenditures \\
\hline Federally Financed Academic \\
Research and Development \\
Expenditures (As Reported in \\
NSF Surveys)
\end{tabular}

Total Academic Research and Development Expenditures (As Reported in NSF Surveys)

Total Academic Research and Development Expenditures Per Full-Time, Tenured, TenureEarning Faculty Member

7B. Other Research and Economic Development Outcomes [for Entire University]*
Development/Research data is a USF system-wide function. Consolidated system data is only available at this time.

Invention Disclosures Received

Total U.S. Patents Issued

Patents Issued Per 1,000 FullTime, Tenure and Tenure-Earning Faculty

Total Number of Licenses/Options Executed

Total Licensing Income Received Jobs Created By Start-Ups in Florida
DATA ARE ONLY APPLICABLE TO TAMPA CAMPUS
Data collection methodology still under discussion. (See endnote.)

* Data will be provided by Board staff for institutions that have reported said data to AUTM. 
7C. Centers of Excellence (Please complete for each Center of Excellence)

\section{Name of Center of Excellence:}

From First

Year Up

To Most

Recent

Most Recent

Year

Year

Research Effectiveness

Competitive Grants Applied For and Received

Total Research Expenditures

Publications in Refereed Journals From Center Research

Professional Presentations Made on Center Research

Invention Disclosures Filed and Issued

Technologies Licensed and Revenues Received

\section{Collaboration Effectiveness}

Collaborations with Other Postsecondary Institutions

Collaborations with K-12 Education Systems/Schools

Collaborations with Private Industry

Students Supported with Center Funds

Students Graduated

Job Placements of Graduates Upon Leaving the Center

Economic Development Effectiveness

Business Start-Ups in Florida

Jobs Created and Jobs Saved in Florida

Specialized Industry Training and Education

$\mathrm{N} / \mathrm{A}$

Dollars Acquired from Venture Capitalists and Other Investments 


$$
\text { N/A }
$$

Insert additional pages, as needed for additional Centers.

7D. Commercialization Assistance Grants

Narrative Comments [Most Recent Year]

$$
\text { N/A }
$$

Insert additional pages, as needed for additional grants. 
8 - Voluntary Support of Higher Education*

Endowment Market Value

(in 2009 Dollars)

Annual Gifts Received

(\$ Amount)

Development/Research data is a USF system-wide function. Consolidated system data is only available at this time.

Percentage of Graduates

Who Are Alumni Donors

* Data will be provided by Board staff for institutions that have reported said data through the NACUBO Endowment Study and the CAE Voluntary Support of Education (VSE) Survey. INCLUDED FOR GOAL \#4.]

\section{ENDNOTES:}

- Currently, teacher certification examination pass rates are reported for program completers only, resulting in a $100 \%$ pass rate (because state-approved programs require passage of the certification exams for completion). Engineering, accounting, architecture, and other professional licensure data, gathered by the respective licensing boards and housed within the Department of Business and Professional Regulation, are not currently formatted and do not contain sufficient information to match to SUS data. Such a match is necessary to develop metrics reflecting pass rates for graduates in those fields. Board of Governors staff will work with individuals from the appropriate agencies to try to get data in the needed format.

- Board staff are continuing to work with the SUS Technology Transfer Directors to determine the best way to capture consistent information regarding Jobs Created By StartUps in Florida in a cost-effective manner.

\section{[Additional definition information will be added to final document.]}


9. Progress on Other Primary Institutional Goals and Metrics As Outlined in the University Work Plan

Provide a report on progress to date on three - five other primary university goals and metrics that were identified in the institution's last annual work plan/proposal.

[NOTE: In 2009, universities may only be able to identify goals and metrics or report on progress on institutional strategic planning goals already in place.] 